\title{
The novel adaptor protein Swiprosin-1 enhances BCR signals and contributes to BCR-induced apoptosis
}

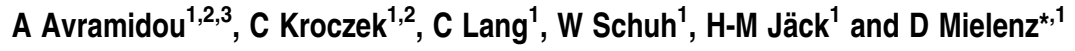

B-cell receptor (BCR) signals are essential for B-cell differentiation, homeostasis and negative selection, which are regulated by the strength and quality of BCR signals. Recently, we identified a new adaptor protein, Swiprosin-1, in lipid rafts of B-cell lines that undergo apoptosis after BCR stimulation. During murine B-cell development, Swiprosin-1 exhibited highest expression in immature B cells of the bone marrow, but was also expressed in resting and activated splenic B cells and in non-lymphoid tissue, especially in the brain. Ectopic expression of Swiprosin-1 in the immature murine B-cell line WEHI231 enhanced spontaneous and BCR-induced apoptosis. In contrast, short hairpin RNA (shRNA)-mediated downregulation of Swiprosin-1 impaired specifically spontaneous and BCR-elicited apoptosis, but not BCR-induced G1 cell cycle arrest and upregulation of the cell cycle inhibitor p27 ${ }^{\mathrm{Kip} 1}$. In accordance, Swiprosin-1 abundance regulated net cell growth of WEHI231 cell populations through reciprocal regulation of $\mathrm{Bcl}-\mathrm{xL}$, but not Bim, thereby controlling spontaneous apoptosis. Swiprosin-1-enhanced apoptosis was blocked through nuclear factor $\kappa$ B-activating stimuli, namely B-cell-activating factor of the TNF family, anti-CD40 and lipopolysaccharide (LPS). This correlated with enhanced BCR-induced I $\kappa B-\alpha$ phosphorylation and degradation in cells expressing a Swiprosin-1-specific shRNA. Finally, ectopic Swiprosin-1 expression enhanced BCR-induced cell death in primary, LPS-stimulated splenic B cells. Hence, Swiprosin-1 may regulate lifespan and BCR signaling thresholds in immature B cells. Cell Death and Differentiation (2007) 14, 1936-1947; doi:10.1038/sj.cdd.4402206; published online 3 August 2007

\begin{abstract}
Antigen-induced positive selection and homeostasis of $\mathrm{B}$ lymphocytes in secondary lymphatic organs are, besides other factors, controlled by the B-cell receptor (BCR). ${ }^{1}$ The IgM BCR complex consisting of two Ig heavy $(\mu)$ and light chains as well as the signaling molecules $\lg \alpha$ and $\lg \beta$ is first presented on the surface of immature $B$ cells in the bone marrow. Here, the BCR is tested for binding to self in order to avoid generation of self-reactive $B$ cells, since failure to establish tolerance during early $\mathrm{B}$-cell development can cause antibody-mediated autoimmune diseases. Immature B cells migrate then as transitional ( $\mathrm{T} 1$ ) $\mathrm{B}$ cells to the spleen where they develop into $\mathrm{T} 2 \mathrm{~B}$ cells and further on develop into mature $B$ cells. At this transition, BCR signaling is essential for survival, ${ }^{2}$ whereby the strength of the BCR signal regulates development of immature B cells into B1-, B2- and marginal zone $\mathrm{B}$ cells. ${ }^{3}$ The quality of the BCR signal is regulated in a developmental manner: $\mathrm{BCR}$ engagement by self-antigen prevents $\mathrm{T} 1 \mathrm{~B}$-cell maturation through clonal deletion, whereas encounter of the BCR in mature $B$ cells initiates proliferation and, with specific costimulation, differentiation into plasma cells. ${ }^{4}$ Since one B cell expresses the same BCR during its differentiation from immature to mature cell and the $B C R$ is required for immature and mature B-cell homeostasis, ${ }^{1,5}$ a key question is how the BCR mediates three
\end{abstract}

physiological outcomes, namely survival, differentiation or apoptosis. One possibility are different BCR signaling modes in immature and mature $B$ cells. ${ }^{4,6}$ Calcium mobilization and tyrosine phosphorylation patterns differ qualitatively in immature and mature $B$ lymphocytes ${ }^{6,7}$ but quantitative differences have also been reported. Specifically, transitional immature B cells in an autoreconstitution system responded to IgM stimulation at five times lower doses of anti-IgM antibodies than mature B cells. ${ }^{7}$ This suggests that the BCR signaling threshold is regulated between immature and mature $B$ cells, possibly by sequential expression of signaling molecules during B-cell development. ${ }^{6,8}$

Another possibility is different compartmentalization of the $\mathrm{BCR}$ in the plasma membrane. Many BCR signaling molecules are concentrated in cholesterol-dependent microdomains (lipid rafts) in the plasma membrane. Lipid rafts therefore represent essential platforms for BCR signaling. ${ }^{9}$ Interestingly, in immature B-cell lines, the BCR appears to be excluded from lipid rafts. ${ }^{10,11}$ Moreover, primary immature, transitional $\mathrm{B}$ cells have lower amounts of cholesterol in their plasma membrane than mature $B$ cells, explaining the failure of the BCR to become stabilized in lipid rafts upon BCR crosslinking in immature $\mathrm{B}$ cells. ${ }^{12}$ Differences in the protein composition of lipid rafts between mature and immature

\footnotetext{
${ }_{1}^{1}$ Division of Molecular Immunology, Department of Internal Medicine III, Nikolaus Fiebiger Center for Molecular Medicine, University of Erlangen-Nürnberg, Germany ${ }^{*}$ Corresponding author: D Mielenz, Division of Molecular Immunology, Department of Internal Medicine III, Nikolaus Fiebiger Center for Molecular Medicine, Glückstr. 6 , Erlangen 91054, Germany. Tel. + 499131 8539105; Fax + 499131 8539343; E-mail: dmielenz@molmed.uni-erlangen.de

${ }^{2}$ These authors contributed equally to this work

${ }^{3}$ Current address: Department of Haemato-Oncology, Brookes Lawley Building, The Institute of Cancer Research, 15 Cotswold Road, Sutton, Greater London SM2 $5 \mathrm{NG}, \mathrm{UK}$

Keywords: B-cell receptor; B-cell tolerance; apoptosis; cell cycle; cell growth

Abbreviations: BCR, B-cell receptor; $\mu \mathrm{Hc}, \mu$ heavy chain; AnxV, Annexin V; PI, propidium iodide; $\Delta \Psi_{\mathrm{m}}$, mitochondrial membrane potential; shRNA, short hairpin RNA; DioC6, 3,3'-dihexyloxacarbocyanine iodide; MAPK, mitogen-activated protein kinase; Erk, extracellular signal-regulated kinase; $1 \kappa \mathrm{B}$, inhibitor of NF- $\kappa$ B; NF- $\kappa \mathrm{B}$, nuclear factor $\kappa$ B; LPS, lipopolysaccharide; BAFF, B-cell activating factor of the TNF family; PL, phospholipase; PKC, protein kinase C; TLR, toll-like receptor; Sw1, Swiprosin-1 Received 20.11.06; revised 21.6.07; accepted 25.6.07; Edited by B Osborne; published online 03.8.07
} 
B cells have also been proposed to account for the disability of the BCR to interact with lipid rafts. ${ }^{13}$ We recently identified a novel potential signaling protein, Swiprosin-1, that is enriched in lipid rafts of two B-cell lines responding to BCR stimulation with apoptosis. ${ }^{14}$ Swiprosin-1 has first been described and named in human CD8-positive T Iymphocytes. ${ }^{15}$

Here, we demonstrate a function of Swiprosin-1. Overexpression of Swiprosin-1 in the immature B-cell line WEHI231 enhanced spontaneous and BCR-induced apoptosis. In contrast, shRNA-mediated silencing of Swiprosin-1 suppressed apoptosis following BCR ligation. Finally, Swiprosin-1 regulated net cell growth of WEHI231 cells through control of spontaneous apoptosis. Our findings support the conclusion that Swiprosin-1 regulates apoptosis and influences BCR signaling in immature B cells.

\section{Results}

Structure and expression of Swiprosin-1. The aim of this study was to characterize Swiprosin-1. Swiprosin-1 is a 240 amino-acid protein with predicted and apparent molecular weights of 27 and $33 \mathrm{kDa}$, respectively. ${ }^{14,15}$ Comparison of amino-acid sequences revealed that mouse Swiprosin-1 (NM_025994) is almost identical to human (NM_024329) $(91 \%)$ and rat orthologues (NM_001031648) (98\%). Rat and human Swiprosin-1 are 93\% identical (Figure 1a). Primary and secondary structure analysis (Figure 1b) showed that Swiprosin-1 putatively contains four myristylation sites, lipid modifications known to play a role in association of proteins with lipid rafts, $^{16}$ three binding sites for $\mathrm{SH} 3$ domain containing proteins, two EF-hand domains and a coiled-coil domain at the $\mathrm{C}$-terminus. These features could indicate a function for Swiprosin-1 as small adaptor protein involved in $\mathrm{Ca}^{2+}$ signaling.

To analyze the expression of Swiprosin-1, we performed Northern blot analysis. As predicted from the cDNA sequence, a Swiprosin-1 message of $2.4 \mathrm{~kb}$ length was detected in spleen, lung and liver with highest abundance in brain and lowest abundance in kidney and thymus (Figure 1c). We further analyzed expression of Swiprosin-1 during B-cell development. Semiquantitative RT-PCR analysis revealed that Swiprosin-1 is expressed throughout B-cell differentiation, with highest expression in immature bone marrow $B$ cells (Figure 1d). In contrast, Swiprosin-2, a close homolog, is expressed only in pro-B cells (our unpublished data). To test whether activation of mature $B$ cells affects expression of Swiprosin-1, mature splenic B cells were stimulated with anti$\operatorname{lgM~F}(a b)_{2} /$ IL-4, LPS or anti-CD40/IL-4. Western blot analysis (Figure 1e) showed that there was no obvious change in Swiprosin-1 expression following stimulation for up to $96 \mathrm{~h}$.

Involvement of Swiprosin-1 in immature B-cell apoptosis. We originally identified Swiprosin-1 in lipid rafts of the immature B-cell line WEHI231. ${ }^{14}$ To characterize Swiprosin-1, we infected WEHI231 cells with a retrovirus encoding Myc-tagged Swiprosin-1 (pSw1Myc) or with empty virus, pMSCVpuro (pMSCV). Expression of Sw1myc was verified by western blotting with anti-Swiprosin-1 (Figure 2a) and anti-Myc antibodies (not shown). Initially, we observed a significant amount of dead cells in puromycin-resistant cultures transduced with pSwiMyc. To investigate whether this was due to apoptosis, we used an early marker, namely loss of the mitochondrial membrane potential $\left(\Delta \Psi_{\mathrm{m}}\right) \cdot{ }^{17}$ Cells were labeled with 3,3'-dihexyloxacarbocyanine iodide (DioC6), a fluorochrome that stains mitochondria in a $\Delta \Psi_{\mathrm{m}}$-dependent manner, ${ }^{18}$ and with propidium iodide $(\mathrm{PI})$, to identify secondary necrotic cells. This revealed an increased frequency of PI-negative cells with reduced $\Delta \Psi_{\mathrm{m}}$ in pSwiMyc-transduced WEHI231 cells, but not in untransduced or pMSCV-transduced cells (Figure 2b), indicating that Swiprosin-1 might induce apoptosis through the mitochondrial pathway. In immature, transitional B cells, BCR stimulation results in induction of apoptosis ${ }^{4}$ and WEHI231 cells serve as a model system for this process. ${ }^{19}$ To examine involvement of Swiprosin-1 in BCR-mediated apoptosis, we analyzed WEHI231wt, pMSCV- and pSw1Myc-transduced cells with AnnexinV (AnxV)/PI staining before and after BCR stimulation (Figure 2d) (representative analysis in Figure 2c). BCR engagement led to an increase in early apoptotic $\left(\mathrm{AnxV}{ }^{+} / \mathrm{PI}^{-}\right)$and secondary necrotic cells $\left(\mathrm{AnxV} \mathrm{V}^{+} / \mathrm{PI}^{+}\right)$in the wt population (total of $17.6 \%$ after $20 \mathrm{~h}$ ) (Figure $2 \mathrm{~d}$ ). However, after 20h, pSw1Myc-transduced WEHI231 cultures contained on the average $61 \%$ total apoptotic cells after BCR stimulation, that is 3.7-fold more apoptotic cells than in wt cells. After $20 \mathrm{~h}$, pMSCV-transduced cells displayed on the average $35.1 \%$ of total apoptotic cells, equivalent to a twofold increase over wt cells. Although pMSCV-transduced cells showed increased apoptosis in this assay compared to wt cells, pSwiMyc-transduced cells were almost twice as apoptotic as pMSCV-transduced cells, indicating a specific Swiprosin-1 effect. When left unstimulated, pSwiMyctransduced WEHI231 cells were on the average more apoptotic (8\%) after $20 \mathrm{~h}$ than pMSCV-transduced $(4.9 \%)$ or wt cells $(4.4 \%)$ (Figure $2 \mathrm{~d}$ ). These results, together with the observation that pSwiMyc-transduced cells displayed a decreased $\Delta \Psi_{\mathrm{m}}$ under normal culture conditions, indicated that overexpression of Swiprosin-1 starts an apoptotic program amplifying proapoptotic BCR signals in WEHI231 cells.

To confirm these data, we silenced Swiprosin-1 stably via expression of a Swiprosin-1 specific shRNA (pshSw1). The empty vector (pSuper; pSp) (Figure 3a) and a vector expressing a scrambled shRNA (pScrambled; pScr) with the same nucleotide content as the Swiprosin-1-specific RNA (Figure $3 \mathrm{~b}$ ) served as controls. After $20 \mathrm{~h}$ of stimulation, pshSw1-WEHI231 cells showed on the average $4.9 \%$ apoptotic cells in comparison to the pSp-WEHI231 cells and wt cells that exhibited 13 or $14.1 \%$ apoptotic cells, respectively (Figure $3 a$ ). This effect was specific since control clones expressing the scrambled shRNA (pScr) exhibited more apoptotic cells than pshSw1 clones (Figure 3b). Thus, it was not simply expression of shRNA that protected WEHI231 cells from apoptosis.

Since the decrease of $\Delta \Psi_{\mathrm{m}}$ (Figure $2 \mathrm{~b}$ ) pointed to activation of the central, caspase-dependent apoptotic pathway, ${ }^{17}$ we investigated whether Swiprosin-1 induced caspase activation. In fact, pSwiMyc-transduced cells exhibited a prominent signal of the large fragment of caspase 7 (p20) (Figure 3c, lane 8 ), representing active caspase 7 . Similar results were 
a

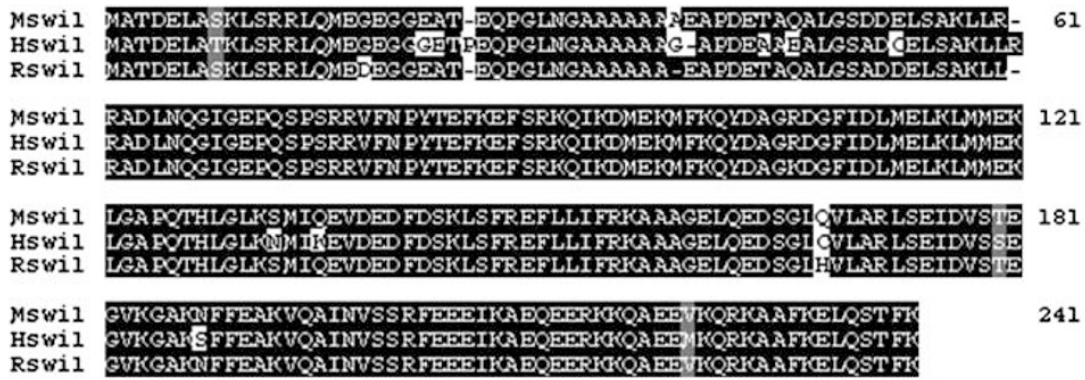

b

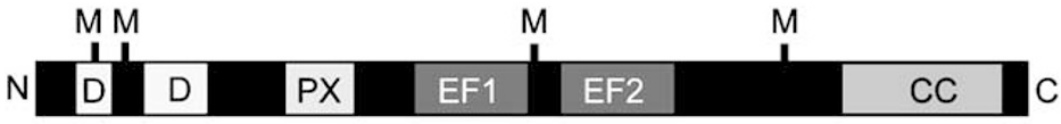

C

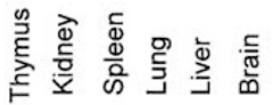

2.4

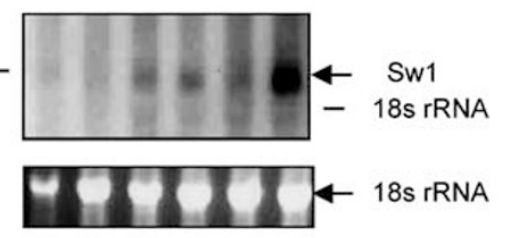

e

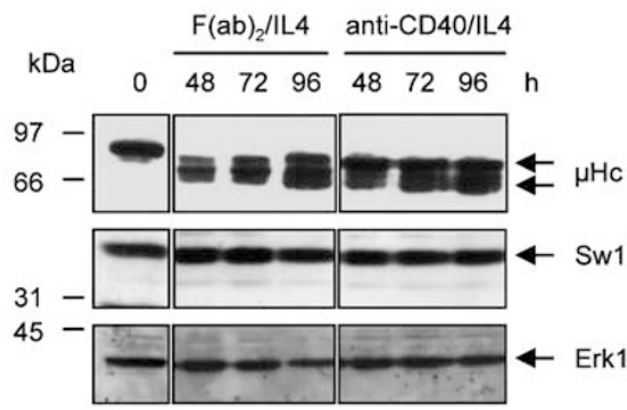

d

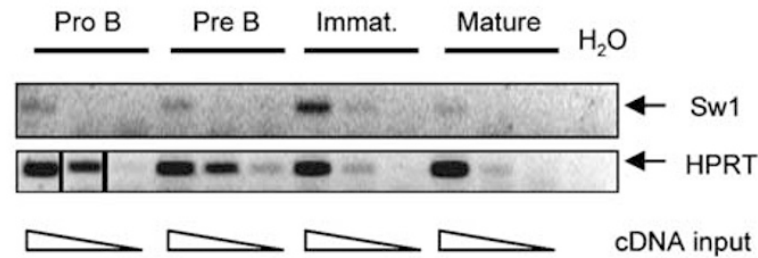

LPS

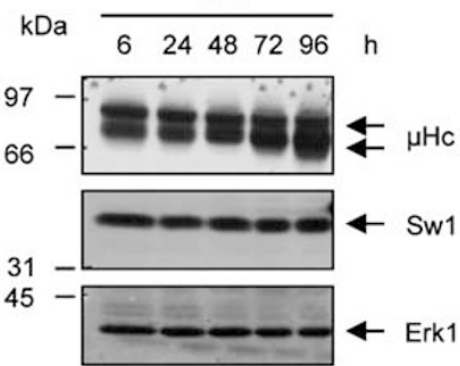

Figure 1 Sequence and expression analysis of Swiprosin-1. (a) Alignment of mouse (M), human (H) and rat (R) Swiprosin-1 (Swi1) amino-acid sequences (accession numbers NM_025994, NM_024329 and NM_001031648). Sequences were aligned at http://www.ebi.ac.uk/clustalw. Black boxes: identity, grey boxes: homologous amino acid, white box: nonhomologous amino acid. Amino-acid positions of murine Swiprosin-1 are shown at the right. (b) Schematic showing the predicted secondary structure (http://elm.eu.org) of Swiprosin-1. M: myristylation site, PX: proline-rich elements (potential SH3 domain-binding sites), EF: EF hands, CC: coiled coil domain. (c) Total RNA from the indicated mouse tissues was used for Northern blot analysis using a Swiprosin-1 (Sw1)-specific probe. Part of the ethidium-bromide-stained RNA gel is shown at the bottom. Molecular mass standards $(\mathrm{kb})$ and positions of $18 \mathrm{~S}$ RNA are indicated. (d) Pro, Pre and immature B cells were isolated by FACS, and mature B cells by MACS. Total RNA from the indicated cells was isolated, reversely transcribed to cDNA and amplified with Swiprosin-1 or HPRT-specific primers in five-fold serial dilutions. (e) Splenic B cells were stimulated with goat anti-mouse IgM F(ab) $)_{2}+\mathrm{IL}-4\left(\mathrm{~F}(\mathrm{ab})_{2} / \mathrm{LL} 4\right)$, with anti-CD40 mAb + IL-4 (anti-CD40/LL4) or with LPS for the indicated times. Cell lysates (30 $\left.\mu \mathrm{g}\right)$ per lane were subjected to western blotting with anti- $\mu \mathrm{Hc}$, anti-Sw1 and anti-Erk antibodies. Molecular mass standards (KDa) are shown on the left. Sw1: Swiprosin-1, $\mu \mathrm{Hc}$ : $\mu$ heavy chain

obtained for caspase 3 (data not shown). Collectively, these data demonstrate that Swiprosin-1 does not only induce, but even appears to be required for BCR-elicited apoptosis of WEHI231 cells.

\section{Swiprosin-1 sets the threshold for BCR signaling and regulates net cell growth of WEHI231 cells. The balance between pro- and antiapoptotic signals in immature B cells determines BCR signaling threshold and survival of immature $B$ cells in the bone marrow. ${ }^{20}$ Since Swiprosin-1 was most abundant in immature B cells (Figure 1d), and since Swiprosin-1 amplified spontaneous and BCR-induced apoptosis in WEHI231 cells (Figure 2d), we speculated that}

the amount of Swiprosin-1 could set the BCR signaling threshold in immature $B$ cells. If this was true, the BCR should elicit a response at much lower antigen doses in cells overexpressing Swiprosin-1. Thus, we treated pSw1Myc-, pshSw1-, pMSCV- and pSp-WEHI231 cells with increasing concentrations of cross-linking anti- $\mu$ heavy chain $(\mu \mathrm{Hc})$ $\mathrm{F}(\mathrm{ab})_{2}$ for $20 \mathrm{~h}$. This resulted in an increase of apoptotic cells in pSwiMyc-, pMSCV- and pSp-cells, concomitant with the concentration of stimulating antibody (Figure 4). However, pSw1Myc-transduced cells exhibited more apoptosis compared to pMSCV cells at each antibody concentration (compare open and filled squares). Moreover, saturation was reached later, namely at $0.75 \mu \mathrm{g} / \mathrm{ml}$, in pSwiMyc-transduced 
cells, whereas a saturating response was reached already at $0.25 \mu \mathrm{g} / \mathrm{ml}$ in pMSCV- and pSp cells. In contrast, pshSw1 cells exhibited almost no apoptotic response (compare open and filled triangles). These results indicated that Swiprosin-1 lowers the BCR signaling threshold, which in WEHI231 cells leads to increased BCR-elicited apoptosis.

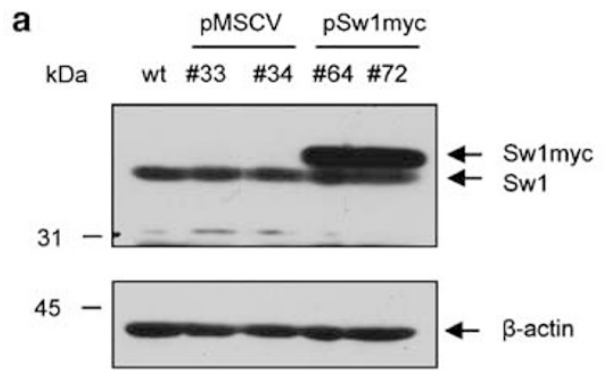

b

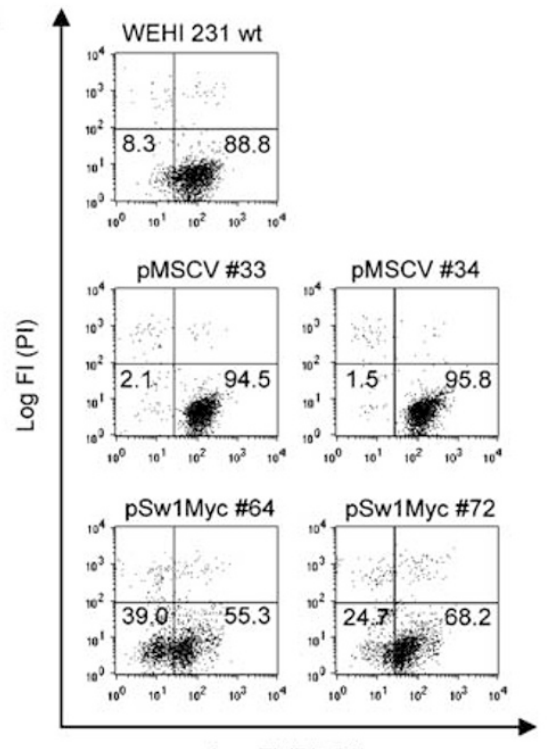

Log FI (DioC6)

C

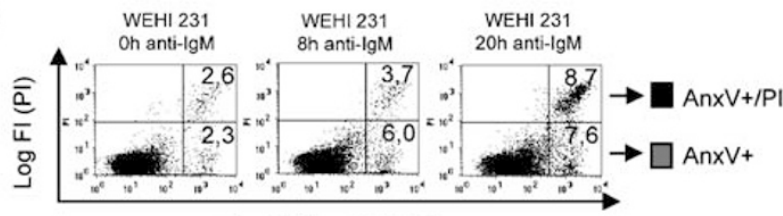

$\log \mathrm{FI}($ AnXV-FITC)

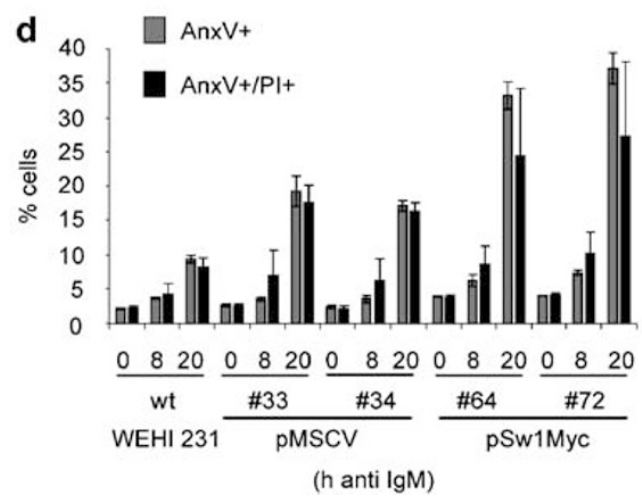

Since we observed spontaneous apoptosis in untreated pSwiMyc-transduced WEHI231 cells (Figure 2), we hypothesized that the amount of Swiprosin-1 protein could also affect net cell increase. Therefore, we analyzed cell growth of pSwiMyc-, pMSCV-, pSp- and pshSw1-WEHI231 cells (Figure 5). Interestingly, pSwiMyc-transduced cultures grew slower than pMSCV- and pSp cells, whereas pshSw1 cells grew faster than pMSCV- and pSp cells. Thus, decreased expression of Swiprosin-1 promotes survival and results in increased WEHI231 populations.

Swiprosin-1 contributes to BCR-induced apoptosis but not to BCR-induced G1 arrest. Net cell growth can also be influenced by cell cycle regulation and in WEHI231 cells, treatment with anti-IgM induces growth arrest in G0/G1 phase. ${ }^{21}$ Thus, we analyzed the impact of Swiprosin-1 on the cell cycle. Figure 6 a displays a representative flow cytometric analysis of WEHI231wt cells with characteristic G1 arrest and an increase of cells with subdiploid (subG1; apoptotic) DNA content after BCR stimulation. ${ }^{21}$ In the absence of antiIgM stimulation, pshSw1-WEHI231 cells in contrast to pSpWEHI231 cells contained a decreased subG1 population and a slightly increased G2/M population after $24 \mathrm{~h}$. After $48 \mathrm{~h}$, only a decreased subG1 peak was visible (Figure $6 \mathrm{~b}$ ). In stark contrast, pSw1Myc-WEHI231 cells displayed increased subG1 populations and decreased G2/M populations both after 24 and $48 \mathrm{~h}$ compared to pMSCV cells (Figure $6 \mathrm{~d}$ ). In the presence of stimulating anti-IgM antibody, pshSw1WEHI231 cells showed a significantly reduced subG1 peak after 24 and $48 \mathrm{~h}$, and increased G2/M populations when compared to pSp-WEHI231 cells (Figure 6c). Conversely, both after 24 and $48 \mathrm{~h}$, pSwiMyc-WEHI231 cells featured strongly increased subG1 populations, concomitant with an accelerated decrease of cells in G2/M (Figure 6e). Of note here is that first, pshSw1-WEHI231 cells did undergo G0/G1 cell cycle arrest after anti-IgM stimulation (Figure 6c) and second, pSwiMyc-WEHI231 cells hardly arrested at G0/G1 but rather went directly into apoptosis (Figure 6e). Thus, BCR-induced G0/G1 arrest takes place also in the absence of Swiprosin-1, but with delayed onset. To verify these data, we analyzed expression of $\mathrm{p} 27^{\mathrm{Kip} 1}$, a cyclin-dependent kinase inhibitor that becomes upregulated after BCR

Figure 2 Effect of Swiprosin-1 overexpression on WEHI231 cells. (a) Lysates from uninfected WEHI231 cells (wt), WEHI231 cells retrovirally transduced with empty vector (pMSCV), or with a Sw1myc-coding vector (pSw1Myc) were analyzed by western blotting with the indicated antibodies. Numbers represent different clones. (b) WEHI231wt, pMSCV and pSw1Myc clones from routine cultures were assessed by PI and DioC6 staining by flow cytometry. Numbers represent the percentage of cells in each quadrant. Representative dot plots of three independent experiments are shown. (c) WEHI231 cells were either left unstimulated or stimulated with $10 \mu \mathrm{g} / \mathrm{ml}$ goat anti-mouse $\operatorname{lgM~F}(\mathrm{ab})_{2}$ for the indicated times. Cells were stained with AnnexinV-FITC (AnxV-FITC) and PI and analyzed by flow cytometry. The gates used to evaluate $\mathrm{AnxV}^{+}$and $\mathrm{AnxV}^{+} / \mathrm{PI}^{+}$cells are indicated in the dot plots. (d) WEHI231wt, pMSCV-and pSw1Myc-infected cells were treated with $10 \mu \mathrm{g} / \mathrm{ml}$ goat anti-mouse IgM F(ab) ${ }_{2}$ fragment for the indicated times, or left untreated for $20 \mathrm{~h}(0)$, and evaluated by flow cytometry using AnxV-FITC/PI staining. Data are presented as mean \pm S.D. of triplicates. Representative results of three independent experiments are shown. Numbers indicate the different clones used in this experiment 


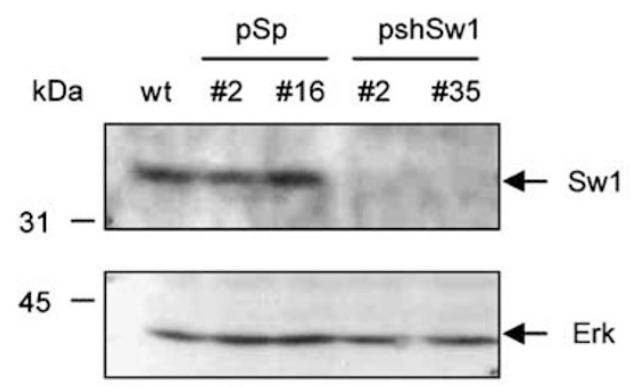

AnxV+

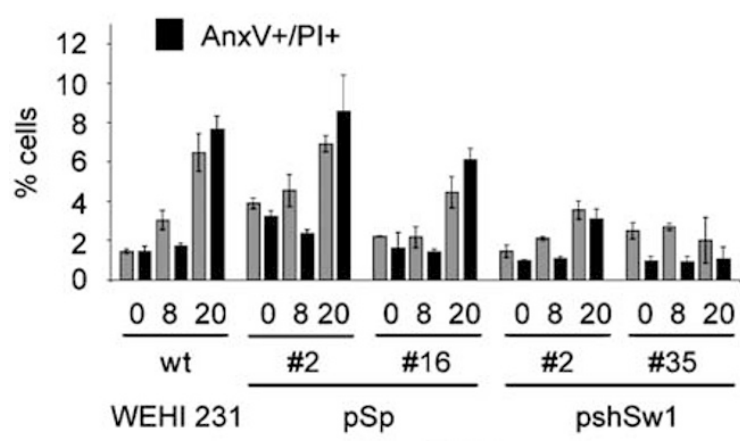

(h anti IgM)

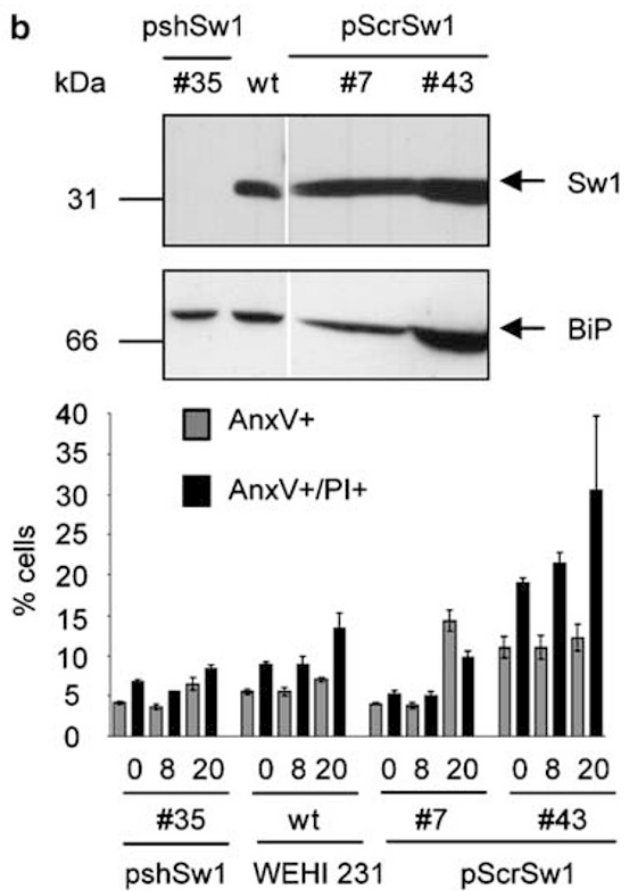

(h anti IgM)

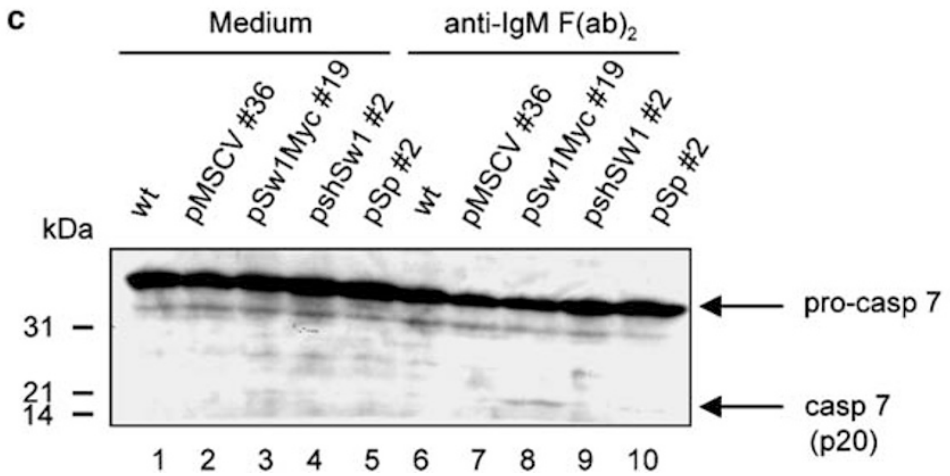

Figure 3 Effect of Swiprosin-1 silencing on BCR-induced apoptosis of WEHI231 cells. (a) Lysates from WEHI231 cells (wt), WEHI231 cells transfected either with empty vector (pSuper; pSp), or with a Swiprosin-1-directed shRNA pSuper construct (pshSw1) were analyzed by western blotting using anti-Swiprosin-1 (Sw1) antibody or anti-ERK1 antibody. Numbers represent different clones. Molecular mass standards $(\mathrm{kDa})$ are indicated on the left. Cells were treated with $10 \mu \mathrm{g} / \mathrm{ml}$ goat anti-mouse lgM F(ab) ${ }_{2}$ fragment for the indicated times, or left untreated for $20 \mathrm{~h}(0)$, and evaluated by flow cytometry using AnxV-FITC/PI staining. Data are presented as mean \pm S.D. of triplicates. Representative results of three independent experiments are shown. (b) Lysates from untransfected WEHI231 cells (wt), WEHI231 cells transfected either with a vector expressing a scrambled control shRNA (pScrambled; pScr), or with a Swiprosin-1-directed shRNA pSuper construct (pshSw1) were analyzed by western blotting using antiSwiprosin-1 (Sw1) antibody or anti-BiP antibody. Numbers represent different clones. Molecular mass standards $(\mathrm{kDa})$ are indicated on the left. Cells were treated with $10 \mu \mathrm{g} /$ $\mathrm{ml}$ goat anti-mouse $\operatorname{lgM~} \mathrm{F}(\mathrm{ab})_{2}$ fragment for the indicated times, or left untreated for $20 \mathrm{~h}(0)$, and evaluated by flow cytometry using AnxV-FITC/PI staining. Data are presented as mean \pm S.D. of triplicates. Representative of two independent experiments are shown. (c) WEHI231wt cells (lanes 1 and 6), pSw1Myc expressing- (pSw1Myc\#19, lanes 2 and 7), Swiprosin silenced- (pshSw1 \#2, lanes 3 and 8) and control WEHI231 clones (pMSCV \#36, lanes 4 and 9, and pSp \#2, lanes 5 and 10) were left untreated (medium) or stimulated with anti-lgM for $18 \mathrm{~h}$. Cell lysates were analyzed by western blotting with caspase 7-specific antibody. Pro-casp 7: procaspase 7, casp 7 (p20): cleaved caspase 7. Molecular mass standards $(\mathrm{kDa})$ are indicated on the left

stimulation in WEHI231 cells to induce G1 arrest. ${ }^{21}$ In keeping with the results of the cell cycle analyses, p27 Kip1 was upregulated 2.2-, 1.9- and 1.8-fold in pSp-, pshSw1 and pMSCV-WEHI231 cells, but only 1.2-fold in pSwiMycWEHI231 cells, respectively (Figure 7a). Thus, Swiprosin-1 overexpression enhances spontaneous and BCR-elicited apoptosis, the latter probably through acceleration of the G1-SubG1 transition. Conversely, downregulation of Swiprosin-1 protects WEHI231 cells from apoptosis, but not from BCR-induced G0/G1 arrest. However, pshSw1WEHI231 cells do undergo apoptosis and G2/M arrest after $\gamma$-irradiation (Supplementary Figure 1).

$\mathrm{Bcl}-2(\mathrm{BH})$ homology proteins, such as Bim or Bcl-xL, regulate apoptosis through formation of pro- or antiapoptotic heterodimers. Since Bim is pro- and $\mathrm{Bcl}-\mathrm{xL}$ is antiapoptotic in primary immature and in WEHI231 B cells, ${ }^{22,23}$ we next examined their abundance. Bcl-xL was roughly three-fold decreased in WEHI231 cells overexpressing Swiprosin-1 
(calculation based on dilution analysis; Figure 7b). We corroborated these results by semiquantitative RT-PCR analysis where we observed a reduction in $B c l-x L$ mRNA (note that $B c /-2$ mRNA was not changed; data not shown).

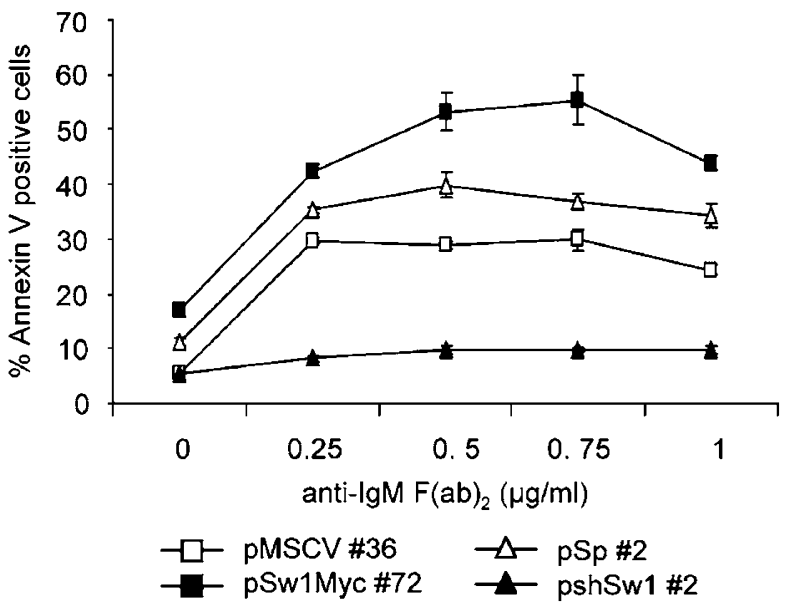

Figure 4 Sensitization of WEHI231 cells towards IgM stimulation though Swiprosin-1. pMSCV\#36, pSw1Myc\#72, pSp\#2 and pshSw1\#2 WEHI231 cells were either left unstimulated or stimulated with the indicated concentrations of goat anti-mouse IgM F $(a b)_{2}$ fragment for $24 \mathrm{~h}$. Cells were stained with AnXV-FITC/PI and analyzed by flow cytometry. Data represent the mean \pm S.D. of $A n \times V^{+}$and $\mathrm{AnxV}^{+} / \mathrm{PI}^{+}$cells of triplicate samples

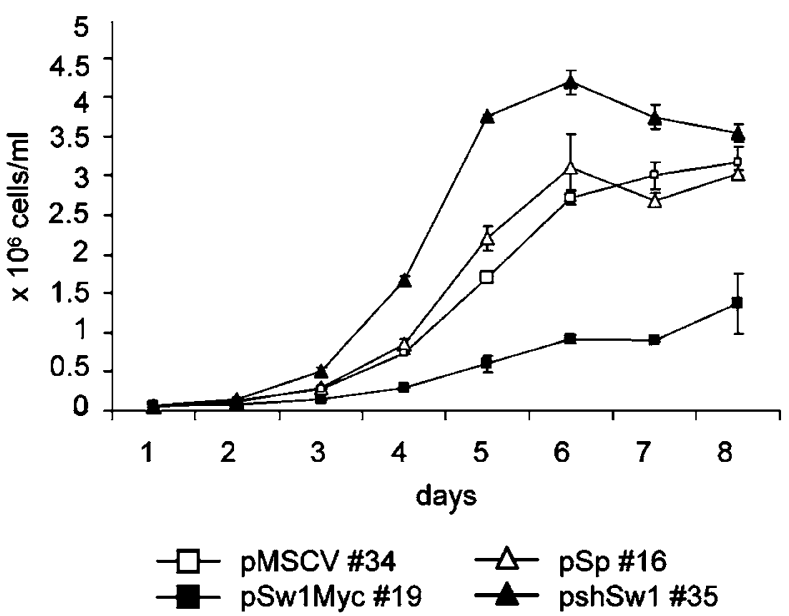

Figure 5 Swiprosin-1 influences growth of WEHI231 cells. pMSCV\#34 pSw1Myc\#19, pSp\#16 and pshSw1\#35 WEHI231 cells were cultured in R10 ${ }^{+}$ medium in duplicates for 7 days. Cell numbers were determined ( $Y$-axis) and plotted against days ( $X$-axis). Representative of five independent experiments are shown
Conversely, Bcl-xL protein was on the average three-fold more abundant in Swiprosin-1-silenced cells compared to control clones (Figure 7c). In contrast, proapoptotic Bim protein was not enhanced (Figure $7 \mathrm{~b}$ ). Taken together, these results indicate that Swiprosin-1 abundance regulates $\mathrm{Bcl}-\mathrm{xL}$ amounts reciprocally on the transcriptional level and thereby influences proapoptotic BCR signaling.

Swiprosin-1 is involved in nuclear factor $\kappa \mathrm{B}$ signaling. The $B C R$ activates the canonical nuclear factor $\kappa \mathrm{B}(\mathrm{NF}-\kappa \mathrm{B})$ pathway where phosphorylation and subsequent degradation of inhibitors of $\mathrm{NF}-\kappa \mathrm{B}\left(\mathrm{I}_{\kappa} \mathrm{B}\right)$ lead to unmasking of $\mathrm{NF}-\kappa \mathrm{B}$ nuclear localization sequences and nuclear import of p50/p65 NF- $\kappa \mathrm{B}$ heterodimers. ${ }^{24,25} \mathrm{Bcl}-x \mathrm{~L}$ is a target gene of the canonical NF- $\kappa \mathrm{B}$ pathway ${ }^{26}$ and thus, cells devoid of Swiprosin- 1 should positively regulate NF- $\kappa$ B in response to BCR stimulation. Indeed, BCR stimulation of pshSw1-WEHI231 cells induced strong $I_{\kappa} \mathrm{B}-\alpha$ phosphorylation (Figure 8a), which was not observed in control cells or in Swiprosin-1-overexpressing cells (Figure 8b-d). Concomitantly, BCR-induced $\mathrm{l} \kappa \mathrm{B}-\alpha$ degradation was enhanced in pshSw1-WEHI231 cells (Figure 8e). In contrast, BCRinduced, transient p42/44-MAPK/Erk (mitogen-activated protein kinase/extracellular signal-regulated kinase) activation was similar in all cell lines examined (Figure 8). Collectively, our data suggest that Swiprosin-1 is part of the BCR signaling pathway and plays a role as negative regulator of the canonical NF- $\kappa$ B-activating branch. In support of this, we observed constitutive colocalization of a Swiprosin-1-EGFP fusion protein with the BCR in unstimulated cells, and partial cocapping with the BCR in BCR-stimulated WEHI231 cells (Supplementary Figure 2).

If decreased NF- $\kappa \mathrm{B}$ activity and decreased abundance of $\mathrm{Bcl}-\mathrm{xL}$ were responsible for increased apoptosis of pSwiMyctransduced WEHI231 cells, activation of NF- $\kappa \mathrm{B}$ should reverse this effect. Coincubation of pSwiMyc-transduced WEHI231 cells with agonistic anti-IgM mAb plus NF- $\kappa$ Binducing stimuli of $B$ cells, namely BAFF (B-cell activating factor of the TNF family), ${ }^{26}$ anti-CD40 $\mathrm{mAb}^{27}$ and LPS (lipopolysaccharide), ${ }^{24}$ alleviated apoptosis in pSwiMyctransduced cells to that of the control cells (pMSCV) (Figure 9a). LPS pretreatment also reduced cell death induced by transient transduction of WEHI231 cells with the GFP-encoding retroviral vector pCru5-Sw1myc-IRES-GFP (9.4-3.6\% after $24 \mathrm{~h}, 64-48.9 \%$ after $48 \mathrm{~h})$, but hardly cell death in empty vector (pCru5-IRES-GFP)-transduced cells (3.8-3.7\% after 24h, 35.3-31.1\% after 48h; Figure 9b). Hence, NF- $\kappa$ B activation counteracts Swiprosin-1-induced apoptosis in immature B cells.

Figure 6 Effect of Swiprosin-1 silencing and Swiprosin-1 overexpression on cell cycle of WEHI231 cells. (a) WEHI231 cells were either left untreated (medium) or treated with $10 \mu \mathrm{g} / \mathrm{ml}$ goat anti-mouse $\mathrm{IgM} \mathrm{F}(\mathrm{ab})_{2}$ (anti-lgM) for $24 \mathrm{~h}$. Cells were stained with Triton X-100/Citrate/PI and nuclei were analyzed by flow cytometry. Representative histograms depict ranges (R) used to distinguish subG1 (R1), G1-G0 (R2), S-Phase (R3) and G2/M (R4). Percentages of cells in each phase of the cell cycle are indicated. (b) pSp and pshSw1 WEHI231 clones (pSp \#2, \#12, \#16, \#17 and pshSw1 \#2, \#35, \#54) were grown in normal growth medium for 24 and $48 \mathrm{~h}$ (medium). Nuclear DNA content was analyzed by flow cytometry. (c) pSp and pshSw1 WEHI231 clones (compare B) were treated with $10 \mu \mathrm{g} / \mathrm{ml}$ goat anti-mouse lgM F(ab) 2 for $24 \mathrm{and} 48 \mathrm{~h}(\mathrm{anti}-\mathrm{IgM})$. Nuclear DNA content was analyzed by flow cytometry. (d) pMSCV- and pSwiMyc-WEHI231 clones (pMSCV \#33, \#34, \#36, \#40 and pSw1Myc \#14, \#19, \#64, \#72) were grown in normal growth medium for 24 and $48 \mathrm{~h}$ (medium). Nuclear DNA content was analyzed by flow cytometry. (e) pMSCV and pSwiMyc WEHI231 clones (compare D) were treated with $10 \mu \mathrm{g} / \mathrm{ml}$ goat anti-mouse $\mathrm{lgM} \mathrm{F}(\mathrm{ab})_{2}$ for 24 and $48 \mathrm{~h}$ (anti-lgM). Nuclear DNA content was analyzed by flow cytometry. Each bar represents average values \pm S.D. for the corresponding four clones. Experiments were validated by a $t$-test but only significant $P$-values are shown. Representative of two independent experiments are shown 


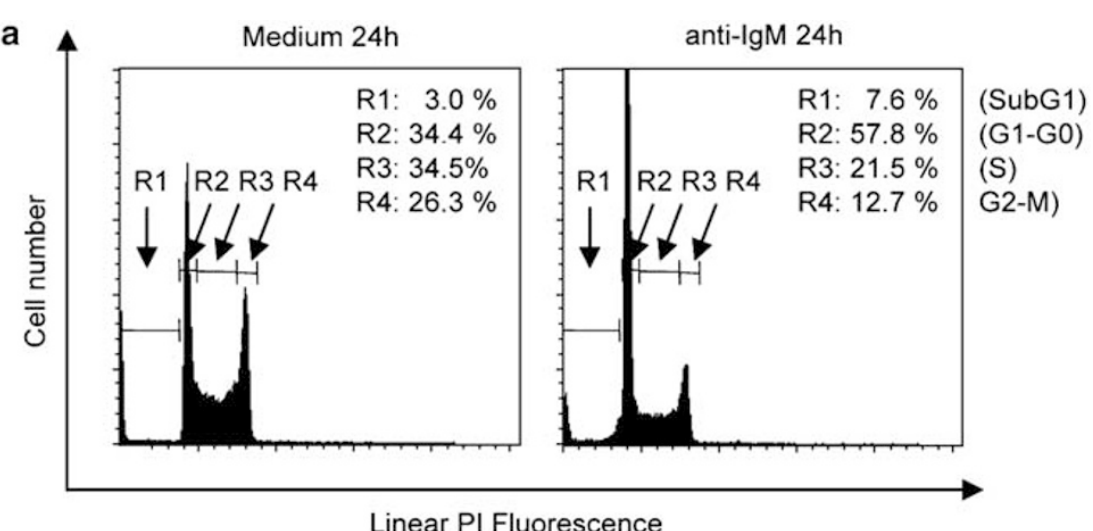

b
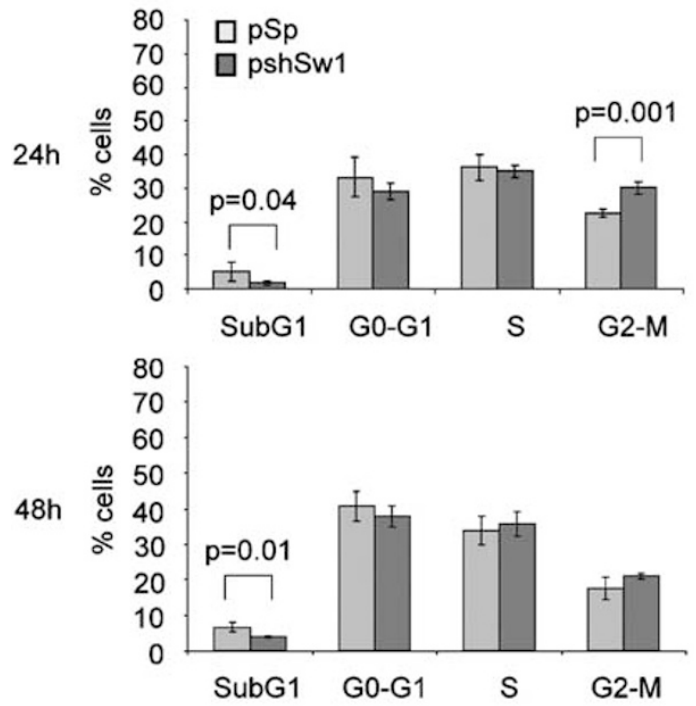

d
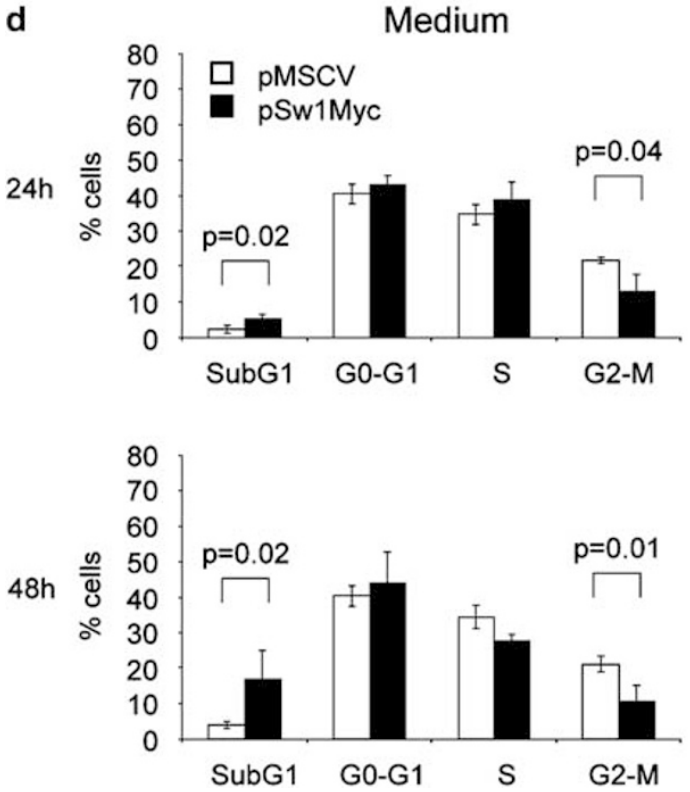

C
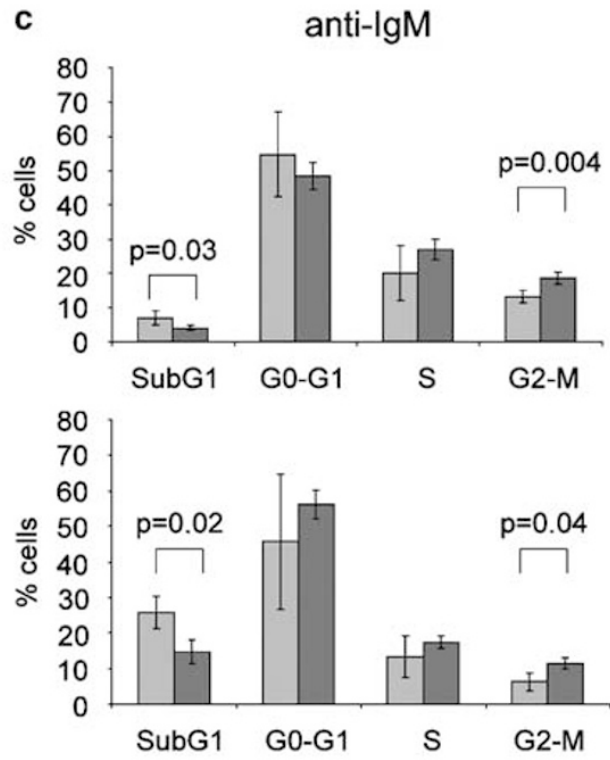

e

80

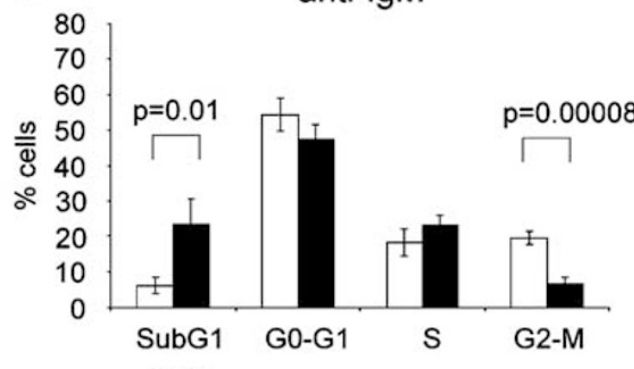
$\mathrm{p}=0.02$

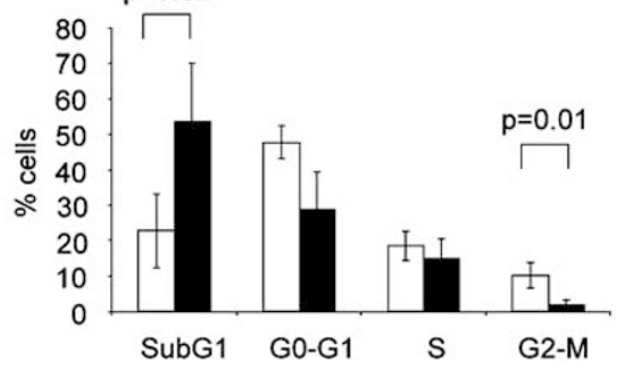

Figure 6 
a

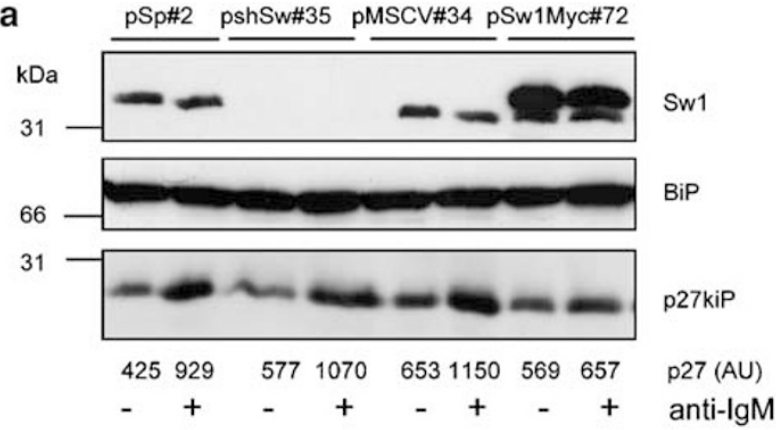

b
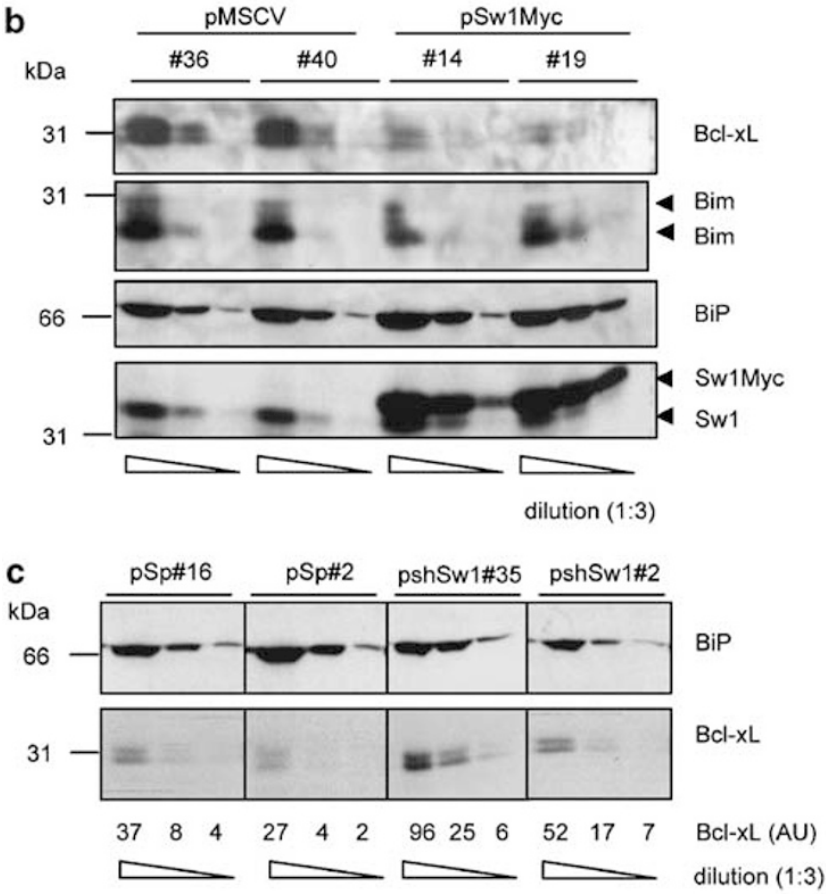

AU Bcl-xL pshSw1\#2 / pSp\#16 : $1.8+1-0.4$

AU Bcl-xL pshSw1\#35/pSp\#2: $4.3+/-1.7$

Figure 7 Effect of Swiprosin-1 silencing and Swiprosin-1 overexpression on p27 $7^{\mathrm{Kip} 1}, \mathrm{Bcl}-\mathrm{xL}$ and Bim expression. (a) Indicated WEHI231 clones were left unstimulated or stimulated with $10 \mu \mathrm{g} / \mathrm{ml}$ goat anti-mouse $\operatorname{lgM~F}(\mathrm{ab})_{2}$ for $24 \mathrm{~h}$. Cell lysates were separated by $10 \%$ SDS-PAGE, transferred to nitrocellulose and probed with antibodies against Swiprosin-1, p27 $7^{\mathrm{Kip} 1}$ and BiP. Molecular mass standards are indicated on the left. Optical densities of $\mathrm{p} 27^{\mathrm{Kip} 1}$ bands are indicated at the bottom (AU). (b) Cell lysates $(80,27$ and $9 \mu \mathrm{g})$ from the indicated clones were separated by $10 \%$ SDS-PAGE and transferred to nitrocellulose. The blot was probed with antibodies against Bcl-xL, Bim, BiP and Swiprosin-1. Molecular mass standards are indicated on the left. (c) Cell lysates $(50,17$ and $6 \mu \mathrm{g})$ from the indicated clones were separated by 10\% SDS-PAGE and transferred to nitrocellulose. The blot was probed with antibodies against Bcl-xL and BiP. Molecular mass standards are indicated on the left. Relative $\mathrm{Bcl}-\mathrm{xL}$ amounts were calculated by comparing Bcl-xL AU of the indicated clones, lane by lane, and are expressed as mean \pm S.D. Images are composed of different regions of the same blot

Swiprosin-1 enhances BCR-induced apoptosis in primary B cells. To investigate the function of Swiprosin-1 in primary $B$ cells, we retrovirally transduced freshly isolated splenic B cells from adult C57BI/6 mice with pCru5-Sw1mycIRES-GFP or the control vector, pCru5-IRES-GFP. Splenic B cells of mature mice are mostly mature, with a $\operatorname{lgM}^{\text {low }} / \lg ^{\text {high }}$ phenotype (Figure 10a), but do contain immature, T1 B cells of the $\mathrm{IgM}^{\text {high }} / \mathrm{IgD}^{\text {low }}$ phenotype, the target of negative BCR selection. $^{2}$ To retrovirally transduce primary $B$ cells efficiently, entry into the cell cycle is necessary and best achieved by preactivating freshly isolated primary $B$ cells with LPS. After BCR engagement, we detected an increase in the frequency of apoptotic cells (AnxV positive) from 38 to $57 \%$ in pSw1Myc-transduced cultures. BCR engagement also increased the frequency of apoptotic cells in primary cultures transduced with the GFP control vector (Figure 10b). However, the difference in the frequencies before and after BCR engagement was clearly smaller in control vectortransduced cells than in pSw1Myc-transduced cells and changed after addition of anti-lgM antibodies only from 55 to $61 \%$. Vice versa, the frequency of live cells decreased significantly after BCR engagement in pSwiMyc-transduced cultures from 61 to $42 \%$, but in control vector-transduced cultures only from 44 to $39 \%$. Thus, Swiprosin-1 appears to amplify proapoptotic BCR signals not only in transformed B-lymphoma cells but also in primary $B$ cells.

\section{Discussion}

Here we report a function of the novel adaptor protein Swiprosin-1 (synonym: Efhd2; www.ensembl.org): Swiprosin-1 regulates specifically apoptosis, but not cell cycling, in an immature B-cell line. During B-cell differentiation and the humoral immune response, regulation of apoptosis is extremely important. For example, only about $3 \%$ of the new $B$ cells generated daily reach the long-lived B-cell pool in the periphery, ${ }^{2}$ and apoptosis controls the pool of activated plasma blasts and selection in germinal centers.

Despite being proapoptotic in an immature B-cell line, Swiprosin-1 is expressed in similar amounts in all murine B-cell lines examined (not shown) and in resting and activated splenic $B$ cells. Thus, there must be mechanisms regulating Swiprosin-1 function. We exclude interactions with Swiprosin2 (Efhd1) because during B-cell differentiation, Swiprosin-2 is only expressed in pro-B cells (unpublished data). Since Swiprosin-1 is likely involved in EGF receptor signaling ${ }^{28}$ and is not exclusively expressed in lymphoid tissue, it probably functions in a cell-type-specific manner. This may be due to different subcellular localization, sequential expression of interacting proteins or cell-type-specific post-translational modifications. Accordingly, Swiprosin-1 was enriched in lipid rafts of two cell lines prone to BCR-induced apoptosis in contrast to apoptosis-insensitive $\mathrm{CH} 27 \mathrm{~B}$ cells. ${ }^{14}$

The amplifying effect of Swiprosin-1 on BCR-induced cell death was reversed by LPS, anti CD40 and BAFF (Figure 9). LPS/TLR (toll like receptor)-4 signals might counteract Swiprosin-1 signals through sustained antiapoptotic activation of $\mathrm{NF}-\kappa \mathrm{B} .{ }^{24}$ In keeping with this idea, $B c /-x L$, an antiapoptotic NF- $\kappa \mathrm{B}$ target gene, was upregulated in WEHI231 cells in which Swiprosin-1 was silenced and downregulated in WEHI231 cells overexpressing Swiprosin-1. These findings are coherent with the notion that, like Swiprosin-1, Bcl-xL abundance regulates BCR-induced apoptosis, but not cell cycle arrest. ${ }^{27}$ Since first, Swiprosin-1 expression is highest in immature, bone-marrow derived $B$ cells and $\mathrm{Bcl}-\mathrm{xL}$ is downregulated in immature $\mathrm{B}$ cells, ${ }^{29}$ 
a

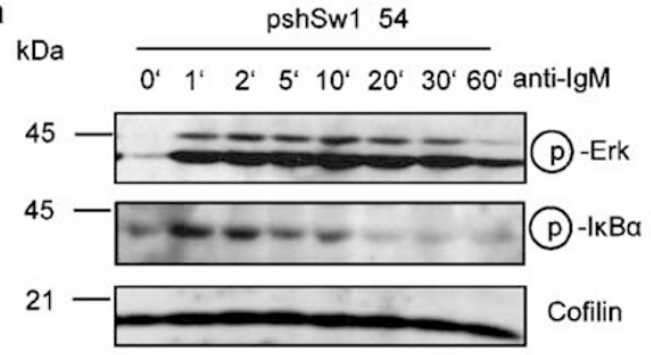

c

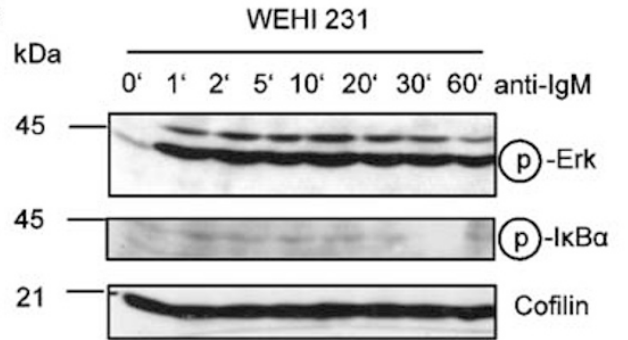

b $\mathrm{kDa}$ psp\#2
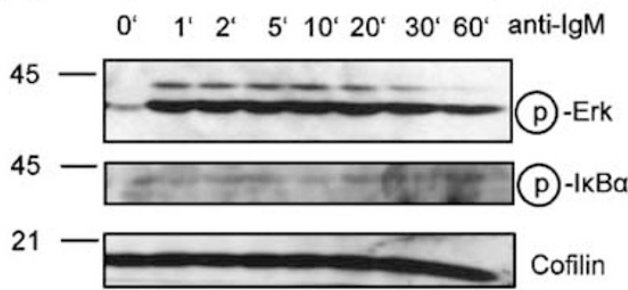

d

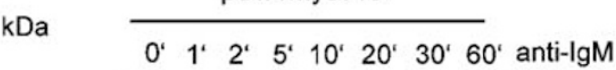
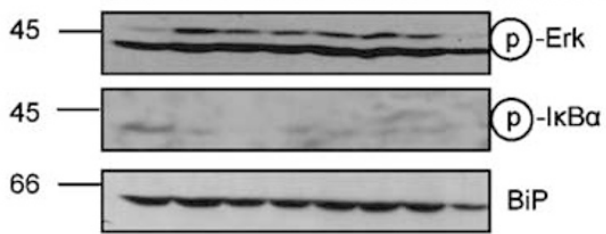
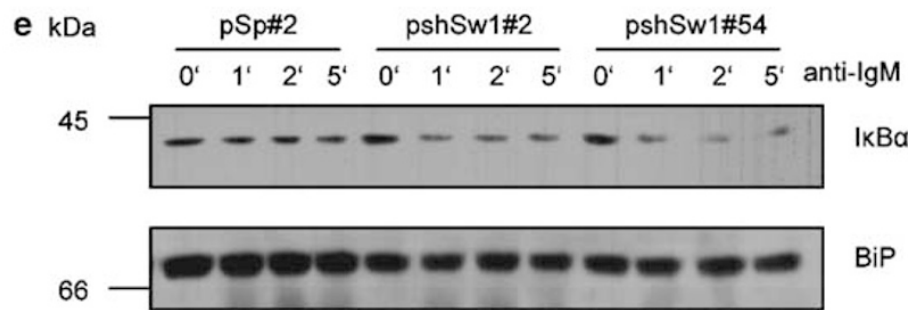

Figure 8 Analysis of $I_{\kappa} B \alpha$ - and p42/44-MAPK phosphorylation in Swiprosin-1-overexpressing and -silenced WEHI231 cells. (a) shSwi1-WEHI231 cells, (b) pSp-WEHI231 cells, (c) wild-type WEHI231 cells or (d) pSwiMyc-transduced WEHI231 clones were stimulated for the indicated times with anti-lgM mAb b.7.6 (5 $\mu \mathrm{g} / \mathrm{ml})$ and cell lysates were separated by $10 \%$ SDS-PAGE. Proteins were transferred onto nitrocellulose and probed with antibodies against phosphorylated p42/44-MAPK/Erk (pErk), phosphorylated ${ }_{1} \mathrm{~B} \alpha\left(\left.\mathrm{p}\right|_{\kappa} \mathrm{B} \alpha\right)$, Cofillin or BiP. Molecular mass standards are indicated on the left. (e) pSp- and pshSw1 clones were stimulated for the indicated times with anti-lgM mAb b.7.6 $(5 \mu \mathrm{g} / \mathrm{ml})$ and cell lysates were separated by $10 \%$ SDS-PAGE. Proteins were transferred onto nitrocellulose and probed with antibodies against I $\kappa \mathrm{B}-\alpha$ and BiP

second, $\mathrm{Bcl}-\mathrm{xL}$ is important for survival of immature $\mathrm{B}$ cells $\mathrm{s}^{30}$ and third, NF- $\kappa \mathrm{B}-$ and Bcl-xL-inducing stimuli, BAFF, antiCD40 and LPS, counteracted Swiprosin-1-induced apoptosis, we propose that Swiprosin-1 expression may contribute to survival and selection of immature $B$ cells via modulation of $\mathrm{BCl}-\mathrm{xL}$ expression. Swiprosin-1 could shift the balance of proand antiapoptotic signals in B cells towards proapoptotic signals by virtue of its abundance. Hence, Swiprosin-1 may be involved in establishing central and peripheral tolerance by regulating the lifespan of immature $B$ cells through induction of a default proapoptotic pathway. This could be balanced by BAFF in T2 and mature B cells, and through LPS or CD40 during $\mathrm{T}$-independent or $\mathrm{T}$-dependent antigenic challenges, respectively.

Overexpression of Swiprosin-1 led to reduced $\Delta \Psi_{\mathrm{m}}$ and caspase 7 cleavage but caspases do not appear to be directly involved in BCR-induced apoptosis in WEHI231 cells. ${ }^{27}$ Thus, the possibility that overexpression of Swiprosin-1 activates the cytosolic phospholipase A2 (PL A2)/cathepsin pathway ${ }^{27}$ in WEHI231 cells is not excluded here. However, we exclude upregulation of proapoptotic Bim and altered Erk signaling as reasons for Swiprosin-1-enhanced cell death because alteration of Swiprosin-1 expression did not affect Erk activation (0-60 min) or Bim expression. Instead, we observed increased
$I_{\kappa} \mathrm{B}-\alpha$ phosphorylation and degradation in pshSw1-WEHI231 cells. Antigen-induced BCR signals stimulate the canonical $\mathrm{NF}-\kappa \mathrm{B}$ pathway, ${ }^{25}$ mediated through the PLC $\gamma 2 /$ protein kinase $\mathrm{C} \beta(\mathrm{PKC} \beta) /$ Carma-1 cascade. ${ }^{31}$ Since silencing of Swiprosin- 1 enhanced BCR-induced $\mathrm{I}_{\kappa} \mathrm{B}-\alpha$ degradation, we suggest that Swiprosin-1 is part of the NF- $\kappa$ B-activating branch of the BCR pathway. Therefore, downregulation of Swiprosin-1 in mature B cells could allow the BCR to trigger the PLC $\gamma 2 /$ PKC $\beta /$ Carma-1 pathway for 'immunogenic' signaling. ${ }^{31}$ In summary, Swiprosin-1 modulates spontaneous and BCR-induced apoptosis very likely through NF- $\kappa \mathrm{B}, \mathrm{Bcl}-\mathrm{xL}$, changes in $\Delta \Psi_{m}$ and activation of post-mitochondrial effector proteases.

Regulation of the lifespan of immature $B$ cells through BCR signaling thresholds has been proposed by several groups (reviewed by Noelle and Erickson ${ }^{32}$ ) and may be determined genetically. ${ }^{33}$ Interestingly, the murine Swiprosin-1 gene is localized only $10 \mathrm{Mb}$ away from the peak marker D4Mit33 in a murine systemic lupus erythematodes susceptibility locus on chromosome $4 .{ }^{33} \mathrm{An}$ intriguing question therefore is whether Swiprosin-1 is regulated under inflammatory conditions? Indeed, Swiprosin-1 appears to be downregulated in PBMC of human rheumatoid arthritis patients. ${ }^{34}$ Downregulation of Swiprosin-1 could therefore not only affect normal B-cell 
a
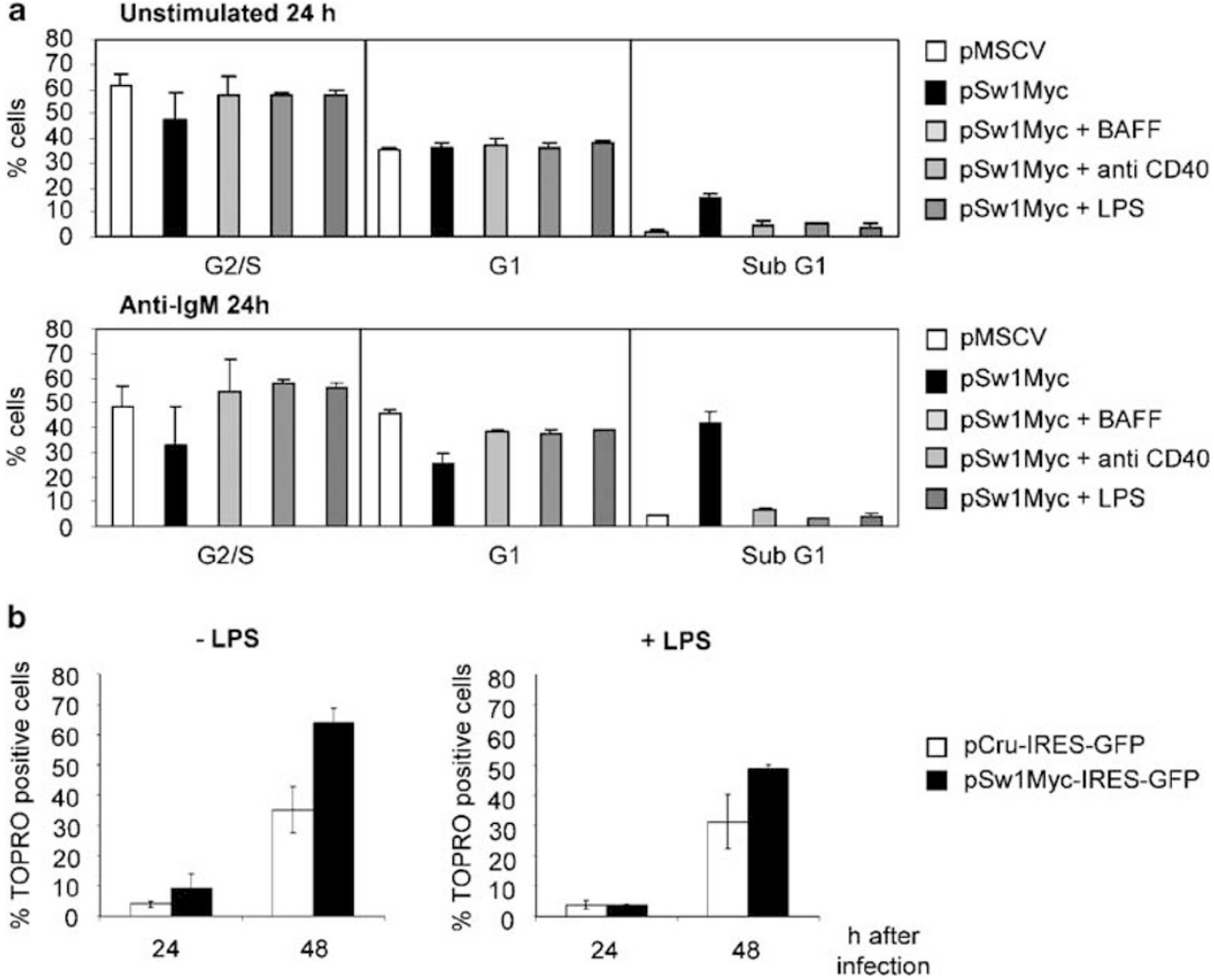

Figure 9 Counteraction of Swiprosin-1-induced apoptosis by LPS, CD40 and BAFF. (a) pMSCV- or pSwiMyc-infected WEHI231 cells (clones 33 and 64) were left either unstimulated or stimulated with $10 \mu \mathrm{g} / \mathrm{ml}$ anti-IgM mAb b.7.6. pSwiMyc-infected WEHI231 cells were incubated additionally with $500 \mathrm{ng} / \mathrm{ml} \mathrm{BAFF,} 10 \mu \mathrm{g} / \mathrm{ml}$ anti-CD40 mAb $1 \mathrm{C} 10$ or $10 \mu \mathrm{g} / \mathrm{ml}$ LPS. After $24 \mathrm{~h}$, nuclear DNA content was analyzed by flow cytometry (G2/M and S-phase were combined). Bars represent average values \pm S.D. from triplicates. Representative of two experiments are shown. (b) WEHI231 cells were left either unstimulated (left diagram) or stimulated with LPS for $24 \mathrm{~h}$ (right diagram) before transient infection with pCru5-IRES-GFP or with pCru5-Sw1myc-IRES-GFP. At 24 and $48 \mathrm{~h}$ after infection, cells were stained with TO-PRO and green cells were analyzed. Bars represent mean \pm S.D. of triplicate cultures

development but also contribute to B-cell abnormalities in autoimmune diseases. ${ }^{32}$

Although WEHI231 cells serve as model system for BCRinduced apoptosis, this cell line is still a murine B-lymphoma cell line. ${ }^{19}$ Since silencing of Swiprosin-1 accelerated net cell growth in WEHI231 cells, reduced Swiprosin-1 protein might contribute to growth of lymphomas, especially because mutations in pro/antiapoptotic genes or enhanced NF- $\kappa \mathrm{B}$ activity often precede secondary mutations affecting cell cycle regulation in aggressive lymphomas. ${ }^{25}$ In summary, our data support the conclusion that Swiprosin-1 determines lifespan and sets the threshold for BCR signaling in B cells, probably predominantly in immature $B$ cells. The generation of mice with a Swiprosin-1-null allele will clarify this issue.

\section{Materials and Methods}

Antibodies and other reagents. Anti-Swiprosin-1 antiserum was described previously. ${ }^{14}$ Rabbit anti-Erk1 and mouse monoclonal anti-Bip were purchased from BD Bioscience (New Jersey, USA), anti-Actin and anti-Cofillin were from Sigma (Deisenhofen, Germany). Rabbit anti-Caspase 7, anti-Caspase 3, anti-p27 ${ }^{\text {Kip } 1}$ (kind gift of Dr. Jean Schneickhardt), phosphorylation-specific antibodies, anti-lkB $\alpha$ and anti-Bim were purchased from Cell Signaling Technology (Danvers, MA, USA) Goat anti-mouse IgM was obtained from Southern Biotechnology, goat anti-mouse IgM $F(a b)_{2}$ fragments were from Jackson Immunolaboratories (distributed by Dianova, Hamburg, Germany). Rat anti-CD40 $(1 \mathrm{C} 10)^{35}$ and anti IgM (b.7.6) ${ }^{36}$ were purified from hybridoma supernatants. IL-4 was from Strathmann (Hamburg, Germany). LPS was purchased from Sigma and oligonucleotides were ordered from MWG Biotech (Ebersberg, Germany). Flag-tagged BAFF was purchased from Alexis Biochemicals (Grünberg, Germany).

Cells. Phoenix-E packaging cells were cultured in DMEM supplemented with $10 \%$ heat inactivated FBS (HI-FBS), $1 \mathrm{mM}$ sodium pyruvate, $50 \mu \mathrm{M} \beta$-mercaptoethanol ( $\beta$-ME) and $100 \mu \mathrm{g} / \mathrm{ml}$ penicillin-streptomycin (all from Invitrogen, Karlsruhe, Germany) at $37^{\circ} \mathrm{C}$ and $7.5 \% \mathrm{CO}_{2}$. WEHI231 cells ${ }^{19}$ and primary murine $\mathrm{B}$ cells were cultured in RPMI 1640 medium supplemented with $10 \%$ HI-FBS, 2 mM L-glutamine, $1 \mathrm{mM}$ sodium pyruvate, $50 \mu \mathrm{M} \beta$-ME and $100 \mu \mathrm{g} / \mathrm{ml}$ penicillin-streptomycin (R10 medium) at $37^{\circ} \mathrm{C}$ and $5 \% \mathrm{CO}_{2}$. Primary murine $\mathrm{B}$ cells were negatively selected from spleens of C57BL/6 mice using anti-CD43 microbeads (Miltenyi Biotec, Bergisch-Gladbach, Germany) and were typically $>95 \%$ pure. Pro-B cells (c-kit ${ }^{+}$, $\left.\mathrm{CD} 19^{+}\right)$, pre-B cells $\left(\mathrm{CD}_{25} 5^{+}, \mathrm{CD}_{19}{ }^{+}, \mathrm{slgM}^{-}\right)$and immature B cells $\left(\mathrm{CD} 25^{-}\right.$, $\mathrm{CD}_{19}{ }^{+}$, slgM ${ }^{+}$) were isolated from bone marrow of $20 \mathrm{C} 57 \mathrm{BL} / 6$ mice and sorted in a MoFlo cell sorter (Dako Cytomation, Glostrup, Denmark). Pro-B cells purified in this manner were $98.68 \%$ pure, pre-B cells were $97.7 \%$ pure and immature $B$ cells were $81 \%$ pure (data not shown). For infection, $B$ cells were isolated from spleens of 16-week-old C57BL/6 mice using positive selection with CD19 magnetic beads (Miltenyi Biotec). Cells were stimulated with $10 \mu \mathrm{g} / \mathrm{ml}$ goat anti-mouse $\operatorname{lgM~F}(\mathrm{ab})_{2} /$ $100 \mathrm{U} / \mathrm{ml} \mathrm{IL-4,} 10 \mu \mathrm{g} / \mathrm{ml}$ anti-CD40/L-4 (100 U/ml) or LPS $(10 \mu \mathrm{g} / \mathrm{ml})$.

Northern blot analysis. Organs of a C57BI/6 mouse were prepared, frozen in liquid nitrogen, homogenized and total RNA was prepared. In total, $10 \mu \mathrm{g}$ RNA per lane were electrophoretically separated, blotted onto nylon membrane (GeneScreen Plus, PerkinElmer, Zaventems, Belgium) and probed overnight with 
a

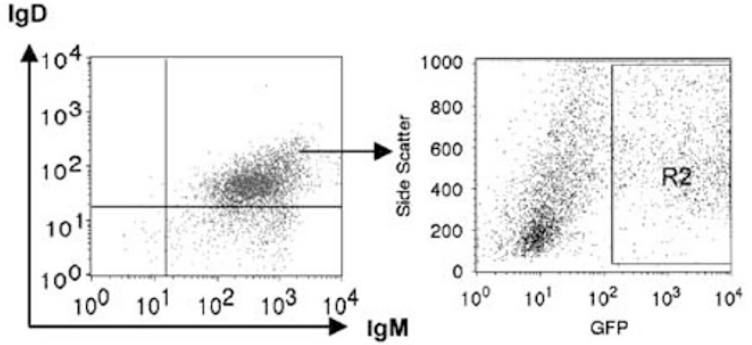

b

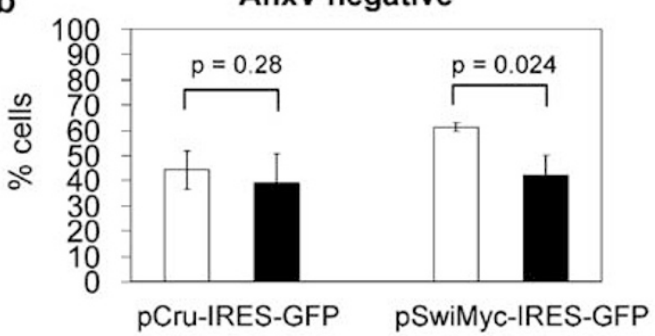

- $+\quad$ - + anti IgM

AnxV positive

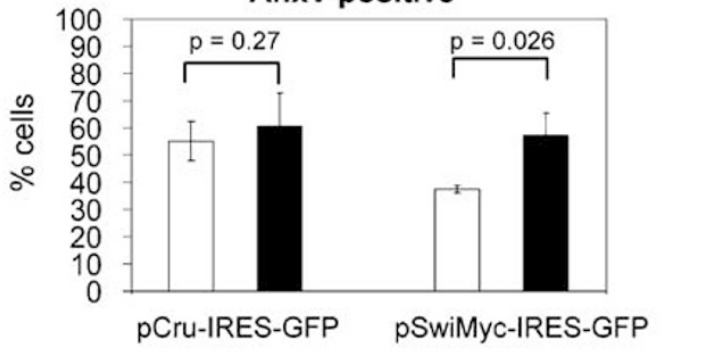

$-\quad+\quad-\quad+$ anti $\lg M$

Figure 10 Effect of Swiprosin-1 overexpression on primary mature B cells. (a) $B$ cells were isolated from spleens of 16-week-old mice by positive selection with anti-CD19 magnetic beads and stained with antibodies against $\mu \mathrm{Hc}$ and $\delta \mathrm{Hc}(\operatorname{lgM}$ $\operatorname{IgD})$. B cells were then transduced with pCru5-IRES-GFP and analyzed by flow cytometry. (b) B cells were transiently transduced with pCru5-IRES-GFP or with pCru5-Sw1myc-IRES-GFP (pSw1Myc-IRES-GFP) after $36 \mathrm{~h}$ of LPS stimulation. At $6 \mathrm{~h}$ after infection, LPS was washed out and cells were either left unstimulated or

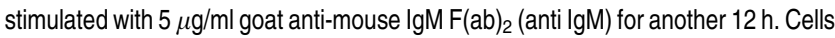
were stained with AnnexinV-Cy3 and ToPro, and green cells (R2) were analyzed. Bars indicate the mean \pm S.D. of unicates from three independent stimulations and infections. AnnexinV-Cy3 negative, ToPro-positive cells were omitted from the calculation

a random prime labeled Swiprosin-1 cDNA probe (RadPrimeDNA Labeling System, Invitrogen). After washing according to standard procedures, bands were detected by autoradiography.

cDNA and plasmids. Murine Swiprosin-1 cDNA was amplified from WEHI231 RNA using the one-step RT-PCR kit (Qiagen, Hilden, Germany). Forward (5'ATGGCCACGGACGAGTTGG-3') and reverse (5'-CTACTTGAACGTGGACTG CAGC- $3^{\prime}$ ) primers were annealed at $60^{\circ} \mathrm{C}$ and the reaction included 35 cycles. The product was cloned into pCR2.1 (Invitrogen) and sequenced. To construct a C-terminally Myc-tagged Swiprosin-1 (Sw1-Myc), murine Swiprosin-1 cDNA was amplified from the pCR2.1-Sw1 vector using Pfu DNA polymerase (Stratagene, La Jolla, USA), with specific forward (5'-GATCGGATCCACCATGGCCACGGACG AGTTGGC-3') and reverse (5'GATCGCGGCCGCCTACAGATCCTCTTCTTCTG AGATGAGTTTTTGTTCCTTGAACGTGGACTG-3') primers. The product was cloned into pCR2.1 and sequenced. The retroviral vector pMSCVpuro-Sw1Myc was constructed by cloning the EcoRI Swiprosin-1-Myc fragment isolated from
pCR2.1 vector into pMSCVpuro (Clontech, Mountain View, USA). To construct a GFP-expressing retrovirus, the Swiprosin-1-Myc cDNA from the pSw1Myc vector was excised with Xhol and Notl and cloned into pCru5-IRES-GFP ${ }^{37}$ to obtain pCru5Sw1Myc-IRES-GFP. A Swiprosin-1-EGFP fusion protein was constructed by PCR with Pfu DNA polymerase, using Swiprosin-1 cDNA and Xhol and BamH1 flanked, Swiprosin-1-specific primers (see above). The PCR product was subcloned into pEGFP-N1 (Clontech), sequenced and finally cloned into pMSCV-Puro using Bgll// Hpal restriction sites. EGFP cDNA was cut out of pEGFP-N1 with BamH1/Not1, subcloned into pCR2.1, cut out again with Bgll/Xho1 and finally cloned into pMSCVPuro to generate pMSCV-GFP.

Retroviral infection of WEHI231 and primary B cells. Viral supernatants were obtained by standard methods. Then, $5 \times 10^{5}$ WEHI231 cells were incubated for $3.5 \mathrm{~h}$ with $10 \mu \mathrm{g} / \mathrm{ml}$ polybrene (Sigma) in $1 \mathrm{ml}$ of retroviral supernatant at $1671 \times g$ and $33^{\circ} \mathrm{C}$. After infection, cells were cultured for $24 \mathrm{~h}$ in fresh medium. Tansduction was repeated $24 \mathrm{~h}$ later and another $24 \mathrm{~h}$ later, cells were selected with puromycin. Stably infected cells were maintained in medium supplemented with $0.4 \mu \mathrm{g} / \mathrm{ml}$ puromycin. Single cell clones were generated out of resistant bulk cultures by limiting dilution and chosen based on equal surface IgM expression. Swiprosin-1-EGFP- and EGFP-expressing WEHI231 cells were not subcloned. For transient infections, isolated primary B cells and WEHI231 cells were infected with pCru5-IRES-GFP or pCru5-Sw1myc-IRES-GFP plasmids only once, following $36 \mathrm{~h}$ LPS stimulation $(10 \mu \mathrm{g} / \mathrm{ml})$. Infection efficiencies were $10-20 \%$ for mature $B$ cells.

Stable knockdown of Swiprosin-1 in WEHI231 cells. The 19nucleotide sequence 5'-GCGTTTGCCTCAGCGGATA-3' (residues 2005-2023 in the murine Swiprosin-1 cDNA sequence, GenBank accession number NM_025994) was inserted as an inverted repeat into the expression vector pSUPERPuro. ${ }^{38}$ As a control, a scrambled shRNA with the same nucleotide content but without significant database match was created and inserted similarly to generate pSUPERPuroscrambled ( $5^{\prime}$-TGGCTCAACGCTTCGAGTG-3'). Then, $2 \times 10^{6}$ WEHI231 cells were transfected with $2 \mu \mathrm{g}$ of vector by nucleofection according to the manufacturer's instructions (Amaxa, Cologne, Germany). At $24 \mathrm{~h}$ after transfection, cells were selected with $0.4 \mu \mathrm{g} / \mathrm{ml}$ puromycin in R10 medium. Stable clones were obtained by limiting dilution out of resistant bulk cultures.

Apoptosis assays, cell cycle analysis and growth curves Apoptosis assays. $1 \times 10^{5}$ cells in $0.2 \mathrm{ml}$ were plated in 48 -well plates in triplicate and left either unstimulated or stimulated with $10 \mu \mathrm{g} / \mathrm{ml}$ goat anti-mouse $\operatorname{lgM~} \mathrm{F}(\mathrm{ab})_{2}$-fragment. Cells were washed with AnnexinV-binding buffer $(25 \mathrm{mM}$ HEPES, $140 \mathrm{mM} \mathrm{NaCl}, 2.5 \mathrm{mM} \mathrm{CaCl}$, pH 7.2) and incubated with $100 \mu \mathrm{l}$ AnnexinVbinding buffer and recombinant chicken AnnexinV conjugated to FITC (Responsif, Erlangen, Germany) for $20 \mathrm{~min}$ at room temperature Samples were then filled up with $400 \mu \mathrm{l}$ AnnexinV-binding buffer including $1 \mu \mathrm{g} / \mathrm{ml}$ propidium iodide (PI). ${ }^{14}$ For analysis of the $\Delta \Psi_{\mathrm{m}},{ }^{18}$ cells were plated in triplicate for $24 \mathrm{~h}$ as above. DioC6 $(80 \mathrm{nM})$ was added for $20 \mathrm{~min}$, cells were washed with cold PBS and resuspended in $500 \mu \mathrm{l}$ cold PBS including $1 \mu \mathrm{g} / \mathrm{ml} \mathrm{PI}$. After infection of cells with the pCru5 constructs, cells were washed once with AnnexinV-binding buffer and filled up with $500 \mu \mathrm{l}$ AnnexinV-binding buffer in the presence of $200 \mathrm{nM}$ TO-PRO-3 iodide (642/ $661 \mathrm{~nm}$ ) (Invitrogen). Cells were analyzed immediately in a FACSCalibur flow cytometer (Becton Dickinson) using CELLQuest software (BD Biosciences).

Cell cycle analysis. Cells were plated as for apoptosis assays, pelleted by centrifugation and resuspended in $500 \mu \mathrm{l}$ hypotonic PI solution containing $50 \mu \mathrm{g} / \mathrm{m}$ $\mathrm{PI}, 0.1 \%$ sodium citrate and $0.1 \%$ Triton $\mathrm{X}-100,{ }^{39} \mathrm{After} 2 \mathrm{~h}$ on ice, samples were analyzed with a FACSCalibur flow cytometer (BD Biosciences).

Growth curves. $1 \times 10^{5}$ cells in $1.0 \mathrm{ml} \mathrm{R} 10$ medium were plated in 24-well plates in duplicates. At the indicated time points, $1 \mathrm{ml}$ cell suspension was pelleted by centrifugation and resuspended in $200 \mu \mathrm{l}$ PBS. Then, $200 \mu \mathrm{l}$ fluorescent beads were added according to the manufacturer's instructions (FLOW-COUNT ${ }^{\mathrm{TM}}$ Beckman Coulter, USA). Living cells were defined by forward/side scatter gating with a FACSCalibur flow cytometer (BD Biosciences) and the absolute cell number was determined. Generally, $24 \mathrm{~h}$ before all assays, dead cells were removed by Ficoll gradient and seeded at $0.5 \times 10^{6} \mathrm{cells} / \mathrm{ml}$.

Western blot analysis. Cells were washed in PBS and lysed in RIPA lysis buffer. Equal amounts of protein were separated by SDS-PAGE ${ }^{40}$ followed by semi-dry transfer onto Protran nitrocellulose membranes (Schleicher \& Schuell, Dassel, Germany), blocked, probed and developed as described previously. ${ }^{14}$ 
Densitometry was performed with AIDA software. Loading was assessed according to a standard protein $(\mathrm{BiP})$ to obtain a correction factor for each lane, allowing quantification of the protein of interest. Protein quantities are expressed as arbitrary units (AU).

Acknowledgements. We thank Drs. Martin Herrmann, Pascal Schneider, Christian Vettermann, Thomas Winkler and Jürgen Wittmann for helpful comments during preparation of this manuscript; Edith Roth for expert technical assistance and Sebastian Dütting for critical reading of the manuscript. This work was supported by grants from the University of Erlangen-Nürnberg (ELAN-Fonds, AZ 05.01.13.1, to $\mathrm{DM}$ ), IZKF Erlangen (TP A7, to DM and HMJ), collaborative research center gran SFB466 from the Deutsche Forschungsgemeinschaft (DFG) (to HMJ), and DFG grant FOR832/1 (TP3, to DM). The authors have no conflicting financial interests.

1. Kraus M, Alimzhanov MB, Rajewsky N, Rajewsky K. Survival of resting mature B lymphocytes depends on BCR signaling via the Igalpha/beta heterodimer. Cell 2004; 117 787-800.

2. Loder F, Mutschler B, Ray RJ, Paige CJ, Sideras $P$, Torres $R$ et al. B cell development in the spleen takes place in discrete steps and is determined by the quality of $B$ cell receptorderived signals. J Exp Med 1999; 190: 75-89.

3. Casola S, Otipoby KL, Alimzhanov M, Humme S, Uyttersprot N, Kutok JL et al. B cell receptor signal strength determines B cell fate. Nat Immunol 2004; 5: 317-327.

4. Carsetti R, Köhler G, Lamers MC. Transitional $B$ cells are the target of negative selection in the B cell compartment. J Exp Med 1995; 181: 2129-2140.

5. Tze LE, Schram BR, Lam KP, Hogquist KA, Hippen KL, Liu J et al. Basal immunoglobulin signaling actively maintains developmental stage in immature B cells. PLoS Biol 2005; 3: e82.

6. Benschop RJ, Brandl E, Chan AC, Cambier JC. Unique signaling properties of B cell antigen receptor in mature and immature $B$ cells: implications for tolerance and activation. $J$ Immunol 2001; 167: 4172-4179.

7. Koncz G, Bodor C, Kovesdi D, Gati R, Sarmay G. BCR mediated signal transduction in immature and mature B cells. Immunol Lett 2002; 82: 41-49.

8. Stork B, Engelke M, Frey J, Horejsi V, Hamm-Baarke A, Schraven B et al. Grb2 and the non-T cell activation linker NTAL constitute a $\mathrm{Ca}(2+)$-regulating signal circuit in $\mathrm{B}$ lymphocytes. Immunity 2004; 21: 681-691.

9. Tolar $\mathrm{P}$, Sohn HW, Pierce SK. The initiation of antigen-induced B cell antigen receptor signaling viewed in living cells by fluorescence resonance energy transfer. Nat Immunol 2005; 6: 1168-1176.

10. Sproul TW, Malapati S, Kim J, Pierce SK. Cutting edge: B cell antigen receptor signaling occurs outside lipid rafts in immature B cells. J Immunol 2000; 165: 6020-6023.

11. Chung JB, Baumeister MA, Monroe JG. Cutting edge: differential sequestration of plasma membrane-associated $B$ cell antigen receptor in mature and immature $B$ cells into glycosphingolipid-enriched domains. J Immunol 2001; 166: 736-740.

12. Karnell FG, Brezski RJ, King LB, Silverman MA, Monroe JG. Membrane cholestero content accounts for developmental differences in surface $B$ cell recepto compartmentalization and signaling. J Biol Chem 2005; 280: 25621-25628.

13. Cherukuri A, Dykstra M, Pierce SK. Floating the raft hypothesis: lipid rafts play a role in immune cell activation. Immunity 2001; 14: 657-660.

14. Mielenz D, Vettermann $C$, Hampel M, Lang $C$, Avramidou A, Karas M et al. Lipid rafts associate with intracellular $B$ cell receptors and exhibit a $B$ cell stage-specific protein composition. J Immunol 2005; 174: 3508-3517.

15. Vuadens F, Gasparini D, Deon C, Sanchez JC, Hochstrasser DF, Schneider P et al. Identification of specific proteins in different lymphocyte populations by proteomic tools Proteomics 2002; 2: 105-111.

16. Melkonian KA, Ostermeyer AG, Chen JZ, Roth MG, Brown DA. Role of lipid modifications in targeting proteins to detergent-resistant membrane rafts. Many raft proteins are acylated, while few are prenylated. J Biol Chem 1999; 274: 3910-3917.
17. Chipuk JE, Bouchier-Hayes L, Green DR. Mitochondrial outer membrane permeabilization during apoptosis: the innocent bystander scenario. Cell Death Differ 2006; 13: 1396.

18. Petit PX, O'Connor JE, Grunwald D, Brown SC. Analysis of the membrane potential of ratand mouse-liver mitochondria by flow cytometry and possible applications. Eur J Biochem 1990; 194: 389-397.

19. Boyd AW, Schrader JW. The regulation of growth and differentiation of a murine B cell lymphoma. II. The inhibition of WEH 231 by anti-immunoglobulin antibodies. J Immunol 1981; 126: 2466-2469.

20. Pelanda R, Torres RM. Receptor editing for better or for worse. Curr Opin Immunol 2006; 18: $184-190$

21. Carey GB, Donjerkovic D, Mueller CM, Liu S, Hinshaw JA, Tonnetti L et al. B-cell receptor and Fas-mediated signals for life and death. Immunol Rev 2000; 176: 105-115.

22. Craxton A, Draves KE, Gruppi A, Clark EA. BAFF regulates $B$ cell survival by downregulating the $\mathrm{BH} 3-$ only family member Bim via the ERK pathway. J Exp Med 2005; 202: $1363-1374$

23. Merino R, Grillot DA, Simonian PL, Muthukkumar S, Fanslow WC, Bondada $S$ et al. Modulation of anti-IgM-induced B cell apoptosis by Bcl-xL and CD40 in WEHI-231 cells. Dissociation from cell cycle arrest and dependence on the avidity of the antibody-lgM receptor interaction. J Immunol 1995; 155: 3830-3838.

24. Hayden MS, Ghosh S. Signaling to NF-kappaB. Genes Dev 2004; 18: 2195-2224.

25. Sasaki Y, Derudder E, Hobeika E, Pelanda R, Reth M, Rajewsky K et al. Canonical NFkappaB activity, dispensable for B cell development, replaces BAFF-receptor signals and promotes B cell proliferation upon activation. Immunity 2006; 24: 729-739.

26. Bossen C, Schneider P. BAFF APRIL and their receptors: structure, function and signaling. Semin Immunol 2006; 18: 263-275

27. Katz E, Lord C, Ford CA, Gauld SB, Carter NA, Harnett MM. Bcl-(xL) antagonism of BCRcoupled mitochondrial phospholipase $A(2)$ signaling correlates with protection from apoptosis in WEHI-231 B cells. Blood 2004; 103: 168-176.

28. Blagoev B, Ong SE, Kratchmarova I, Mann M. Temporal analysis of phosphotyrosinedependent signaling networks by quantitative proteomics. Nat Biotechnol 2004; 22 : 1139-1145.

29. Grillot DA, Merino R, Pena JC, Fanslow WC, Finkelman FD, Thompson CB et al. Bcl-x exhibits regulated expression during $B$ cell development and activation and modulates lymphocyte survival in transgenic mice. J Exp Med 1996; 183: 381-391.

30. Fang W, Weintraub BC, Dunlap B, Garside P, Pape KA, Jenkins MK et al. Self-reactive B lymphocytes overexpressing $\mathrm{Bcl}-\mathrm{xL}$ escape negative selection and are tolerized by clonal anergy and receptor editing. Immunity 1998; 9: 35-45.

31. Jun JE, Goodnow CC. Scaffolding of antigen receptors for immunogenic versus tolerogenic signaling. Nat Immunol 2003; 4: 1057-1064.

32. Noelle RJ, Erickson LD. Determinations of $B$ cell fate in immunity and autoimmunity. Curr Dir Autoimmun 2005; 8: 1-24.

33. Wakeland EK, Liu K, Graham RR, Behrens TW. Delineating the genetic basis of systemic lupus erythematosus. Immunity 2001; 15: 397-408.

34. Dotzlaw H, Schulz M, Eggert M, Neeck G. A pattern of protein expression in peripheral blood mononuclear cells distinguishes rheumatoid arthritis patients from healthy individuals. Biochim Biophys Acta 2004; 1696: 121-129.

35. Heath AW, Wu WW, Howard MC. Monoclonal antibodies to murine CD40 define two distinct functional epitopes. Eur J Immunol 1994; 24: 1828-1834.

36. Julius $\mathrm{MH}$, Heusser $\mathrm{CH}$, Hartmann $\mathrm{KU}$. Induction of resting $\mathrm{B}$ cells to DNA synthesis by soluble monoclonal anti-immunoglobulin. Eur J Immunol 1984; 14: 753-757.

37. Lorens JB, Jang Y, Rossi AB, Payan DG, Bogenberger JM. Optimization of regulated LTRmediated expression. Virology 2000; 272: 7-15.

38. Wittmann J, Hol EM, Jäck HM. hUPF2 silencing identifies physiologic substrates of mammalian nonsense-mediated mRNA decay. Mol Cell Biol 2006; 26: 1272-1287.

39. Nicoletti I, Migliorati G, Pagliacci MC, Grignani F, Riccardi C. A rapid and simple method for measuring thymocyte apoptosis by propidium iodide staining and flow cytometry. $\mathrm{J}$ Immunol Methods 1991; 139: 271-279.

40. Laemmli UK. Cleavage of structural proteins during the assembly of the head of bacteriophage T4. Nature 1970; 227: 680-685.

Supplementary Information accompanies the paper on Cell Death and Differentiation website (http://www.nature.com/cdd) 